\title{
DISCRIMINATION ABILITY OF THE SOUND FROM FRONT AND REAR SOURCES (DFR)
}

By

KONEN FUJII

\section{From the Department of Otorhinolaryngology Osaka University Medical School (Director: Prof. T. Hasegawa)}

1) Amoung the earlier studies on the directional hearing, there have been few on the discrimination ability of the sound from front and rear sources (DFR). Foundamental study on this ability was performed to establish the test method, and various kinds of hearing disorders were tested.

2) The method was as follows:

Two loudspeakers were set in front of and in the back of the subject at the same distance.

Pure tone, white noise and bandpass-noise of the same loudness were given from the two speakers. The subjects were told to answer where the sounds came from.

3) When a subject kept his head still.

i) The wider the frequency range of the testnoise, the better the DFR.

ii) To elicit good DFR, the duration and the intensity of the testnoise should be more than $0.25 \mathrm{sec}$ and $40 \mathrm{db}$ (SL) respectively.
DFR was not significantly influenced by the rise and decay time of the testnoise.

iii) Concerning the azimuth of the sound sources, the best DFR was obtained when the sources was $30^{\circ}$ to $45^{\circ}$ apart from the median sagittal plane.

iv) When earplugs were inserted in the both earcanals, DFR was disturbed, but the effect of auditory fatigue was not so re. markable as earplugs.

4) When the head of subject was moving, narrow bandpassnoise was also well discriminated as white noise.

5) DFR of the subjects with hard deafness was poor in proportion to the degree of hearing loss.

6) DFR was poor in the presence of central disorders, even when the hearing was normal.

The last result indicates the possible usefulness of the test as a diagnostic aid of central disorders.

\section{音の前後感覚に関する基礎的ならびに臨床的研究}

大阪大学医学部耳舆咽喷科学教室（主任：長谷川高敏教授)

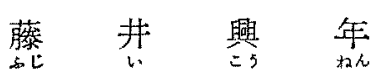

目次

1 楮言

】基碟的研究

A 前徭觉枱盉法

B 前後觉の一般的研究

1) 枱査音の䣶類について

2）検查音の持続時間について

3）検查の場について

4) 小 括

$11-33$
C Noise を検查音とした前後觉の破究

a）俻查音の性質々前後党

1）持続時間上周波数成分

2）立上り立下り时阔の影響について

3）音量の影響について

4）音源の位蹎について

5) 小 括

b) 被检者佩の条件:

1) 性別飞つい, 
2) 年令について

3) 頭部速動の影響について

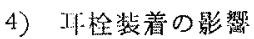

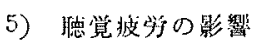

6) 小 拈

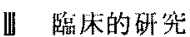

\begin{tabular}{|c|c|}
\hline A & 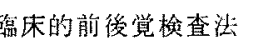 \\
\hline B & 剈後覚の判定についてて \\
\hline $\mathrm{C}$ & 各種垁患と前後覚 \\
\hline 1) & 神経性耳䳚 \\
\hline 2) & 神経性難聴 \\
\hline 3) & 僈性中耳炎 \\
\hline 4) & 1 側 奞 聴 \\
\hline 5) & メニエル氏病 \\
\hline 6) & 用枢疾慗 \\
\hline 7) & 外耳疾患 \\
\hline $\mathrm{D}$ & 括 \\
\hline 考 & 按 \\
\hline 結 & 語 \\
\hline & 交献 \\
\hline
\end{tabular}

\section{I 緒}

筸の聞えてくる力问を識別し，さらに筸源迄の距離を

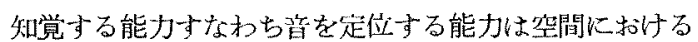
自己の Orientation に関保する重要な感覚の一つであ る.さらに近年交通戦争にあけくれる日常生活上，警笛 や車の騄音を定位し注意する上でますます重要な感覚と なつてきた。また単に物音の所在を知るばかりでなく音 の方向党は騒音下での語音明瞭度を゙良くする働きもあ る。このように音の方向覚は我々の生活と密接な関係を 有するが，近年後迷路珄難聴の䛦断を目的として両耳聴 検査がとりあげられ，その一つとして方向感覚が重要視 されるようになつてきた。

從来の方向感検査法を大別少ると二通りあつて一つは 聅際の音を直接聞かせる万法で，他の一つはレシーバー を通して聞か好る力浩で，後者の力が研究上何かと便利 である、とこるで耐耳にあてたレシーバーを通してステ レオのレコードを聞いてみると立体感はどこがへ行つて しまつて晢はなるほどか所からではなく移動して聞え てくるが，いづれも頭蓋内あるいは後頭部附近から聞 え，決して頭蓋を離れて前力からは聞えてこない，両耳 に入るこれらの音には時間差，位相差，強度差などがつ いているにかかわらず 前少感と距離感を与える何か が欠けているわけである。両耳にレシーバーをあてて dichotic な音を聞かせる方向感検查法でも同様に左右 感は生じるが，前方感と距離感にそしい音で生の耳で聞 いたよらに聞えないので，それだけ定位は困難となる。 このように音の前後感は左右感とは異つた条件で規定さ れているよらにみ克る。

音の方向感覚を規定する条件として，従来雨耳に到達 する音の間の時間差，位相差，強度差，波型差があげら れ，種々研究されている。これらの条件は単独でも方向 感をつくりだす上に生の耳で聞いた場合はそれらが互に 組合わさつて方向感をつくりだすのでその解折が難かし く, 従来の方向感研究成續にいろいろの違い考生しててい る原因の一のと考光られる，音の定位能を力向感覚之距 離感覚とに分け，さらに方向感覚を前後感覚と左右感覚 と上下感登に分けて考觉るとこれらの4つの条件の働き 万の解明が容易になると考点られる。

今音源が音を聞く人の正中面（䫓の中心を通る知状 面）上にある時は両耳に入る音の間には時間差，位相 差，強度差，波型差がない，また正中面上になくて左右

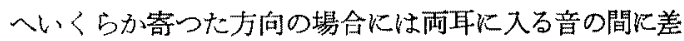
が生じるが，時間差，位相差で同じ量の差を生じる点が 図 $\mathrm{l} b$ b $\mathrm{b}^{\prime}, \mathrm{c}$ と $\mathrm{c}^{\prime}$ のごとく前にも後にも存在する からこの二つの条件では音の前後を弁別できない筈であ る。そこで央際上果して前後が弁別できるのができな いのか，またできるならばいかなる手掛りによつて前後 を升別しているのかが問題となる.

從来の力向覚砄究に打いて特にこの音の前後感の起り 方について注目し，鿬究している報告は殆んどみられた い. 僅か心 Stevens \& Newman が2人の被検者を用 い，ビルの屋上にて純音についての前後感覚を報告し， 大内らが 10 名の被检者を用い純音について音源の方角 を誤る角度（主観的方角と客観的方售との差）之周波数 との関係をみている中で前後感覚に触れている程度に過 ぎないよつてここに前後の音の弁別を通じて音の前後 感の起り万についての基礎的矿究を行つた.ささらに前後 覚検査に最適な方法を考光，各種疾患々者の前後覚につ いてしらべた．以上の結果上り音の前後感の起り方につ いて考察し，前後覚検查が中枢診断法として用いられる 可能生を見出した。

\section{II 基碮的研究}

我々はいかなる手掛りによつて音の前後を判断してい るかを調べるために各種の基礎的検查を行つた，検査対 象として耳鏡検疽にて外耳豉膜に異常を認めず，純音聴 力閶值が 上10db 以内で他に身体に異常の認められな 
い健康人（以後正常人と称す）総数 315 名について音の 前後感覚（以後前後覚と称す）をしらべた。

\section{A 前後覚検查}

因 $1 \mathrm{a}$ - $\mathrm{a}^{\prime}$ のごとく被検者の正中前後同一距離に音源 （スピーカ）を置くか，あるいは $\mathrm{b}-\mathrm{b}^{\prime}$ や c-c' のごとく 両耳を通る前額面に対称に音源を配置し，予めテープに 録音してある各種の音を鳴らす。

图 1 被検者と音源の配膡(上かららみたところ)

a

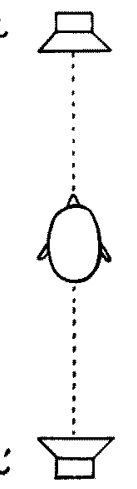

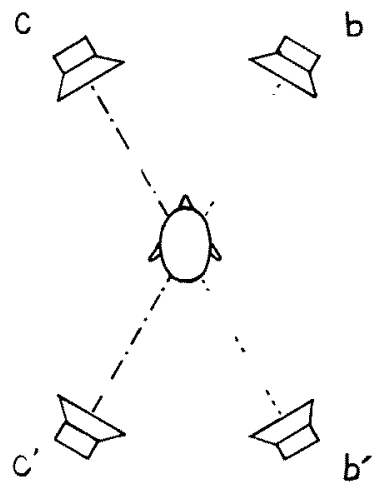

闑眼させた被検者に頭を動かさぬよらに注意を与え， 聞えた音の前後を答えざせた。

検査音は子かテープに録音してあり，この録穴は次の ようにして行つた。

オージオメーター（リオンA-1002D型）電子スイッ

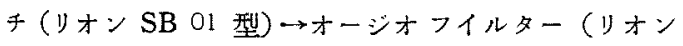
SA 2701 型) $\rightarrow$ スデレオテーブレコーダー (ソ=-521 型).

再生は同じテープレューダーを用い $25 \times 25 \times 17 \mathrm{~cm}$ のスピーカーポックスに入つたスピーカー(パイオニフ PAX 16A 型) 2 ケ鳴らした。

前後筧の判定として聞かせた検查音の数の内いくつ (何\%) 前後を誤りあるいは不明となるかを指標とした。 $50 \%$ 以上䜋るものは不良で50\%以下少くなる程前㖟覚 良好とい壳る。

\section{B 前後筧の一般的研究}

1) 検査音の種類について（娭查 1 )

検査音として 125 8000 cps の純音, White Noise (WN)，会話怙よび楽音を用い $5.0 \times 4.0 \times 3.5 \mathrm{~m}$ の室で 被検者の正中前後 $2.0 \mathrm{~m}$ より1回つつ順不同で聞か心 た。検查音の持続時閒 $5.0 \mathrm{sec}$ 㞱上り立下り時間（Rise and Decay Time) $1.0 \mathrm{sec}$, 強さ Sensation Level (SL)
$50 \mathrm{db}$ である、28〜40才の正常人15名（す13名영） について行つたところ，125４000cps の純音では前後 を誤る扣よび不明の率は $40 \%$ 前後であるが， $8000 \mathrm{cps，}$ WN，会話怙よび楽音では $10 \%$ 前後であつた。

2) 検查音の持続時間について

検查 1 の持続時間 $5.0 \mathrm{sec}$ とい5のは長すぎて，检查 音の鳴り終らない内に答える人や検查音の鳴つている最 中に頭を動かす人が㷴々みられた（後述するが頭を動か すと前後覚はずつと良くなる)。厹こで検査音の持続時 間を短くした。

i）純音北よび雑音の場合（榆查 2 )

検査音は $125 \sim 8000 \mathrm{cps}$ の純音，Pulse Noise (PN) および WN で持続時間は 0.25sec と $1.0 \mathrm{sec}$, 立上り立 下り時間 $25 \mathrm{msec}$ のものである。これらを正中前後よ り2 回ふつ19 40才の正常人15名（す11名果4名）に ついて㮌不同で聞かせたところ，125～8000 cps の純音 では $0.25 \mathrm{sec}$ 音で前後を誤る执よび不明の数の\%は 40 〜 50\%で，1.0sce 音で 30〜45\%であつた，複合音では $0.25 \mathrm{sec}, 1.0 \mathrm{sec}$ 音共 15 20\%である。

ii）語音の場合（娭査 3 )

会話や湶音は持続時間を短くすると，その時の切断の 具合でいろいると音が変化し，さらに短くするともはや 会話や楽音とはい充なくなる，それで会話を短くした最 小の状態すなわら単音について前後覚をしらべた，用い た音は語音明瞭度検查用レコードからテープに録音した

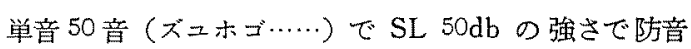
聴力娭查室にて正中前後 $1.0 \mathrm{~m}$ 上り聞か忧た，被検者は $20 \sim 38$ 才の正常人 10 名（す4名96名）で結果恃図2 のごとくである，因2では単音を10ケづつ区切つて横 朝に表わしてあるが始めと終りで少し差があり，始めの 10 音については検査 1 の $5.0 \mathrm{sec}$ 音の会話や楽音よりも

图 2 単音に対する前後党

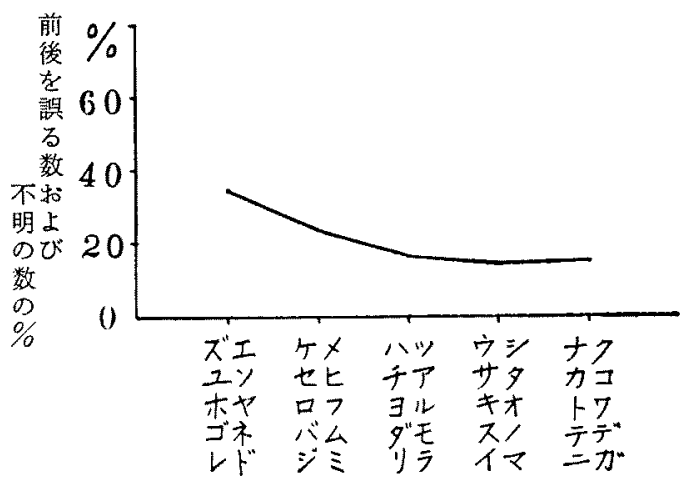




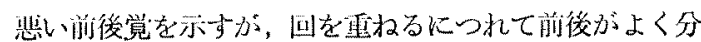
るようになつてくる。

3）検查の場について (椧查 4 )

梌查 1,2 は普通の硎究室にて行つたが，部屋の反整が 多く，また室の二方が空で完全に 前後左右が刘称でな く，外来の雑音も聞えやすい，そこで検查の場所を裂え ても同じ結果が得られるかどうかを調べるため, 当教室 の防音聴力检查室を用いて同様の検查を行つた，室の広 さは $2.1 \times 2.4 \times 2.4 \mathrm{~m}$ で天井と壁はガラスゥールと布を 張つて可及的反響を少くしてあり，外来音の遮音効果は 約60フォンである.この室の中央に被検者を座らせ正中 前後 $1.0 \mathrm{~m}$ の所より音を聞かせた。検査対象は 20〜35 才の正常人10名（36名94名）で得られた結果は図 3 に示す

図 3 純音括上び複合音の前後觉

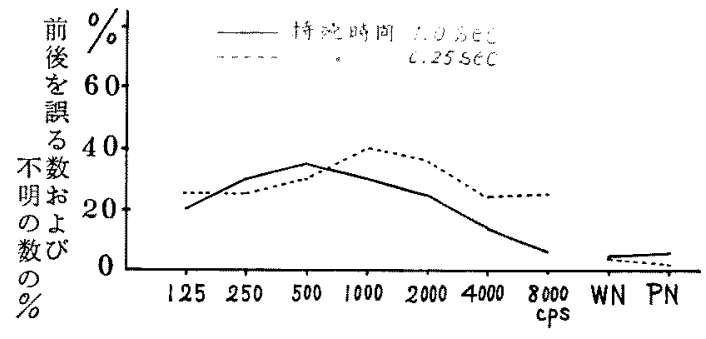

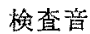

この結果を検查 2 と比較すると大体の傾向には变りは ないが，全体汇前後を誤る拉よび不明の率がやや低く また持続時問 $1.0 \mathrm{sec}$ 群の $4000,8000 \mathrm{cps}$ 音では雑音に 近い前後賞を示した。

4) 小 括

1) 19 40 才の正常人総数 50 名（古34名古16名）の 正中前後より各種の音を聞かせて前後覚をしらべた。

2）純音は $8000 \mathrm{cps}$ 索除き般に前後が弁別し難い が複合音は比較的容易である。

3）検查音の持続時間 5.0，1.0扣よび $0.25 \mathrm{sec}$ 群の 間には $8000 \mathrm{cps}$ 音を除き著差は認められない。

4) 単音は会話に比して前後が分りにくいが，検查を くり返すと前後の弁別が多少良くなる例がある。

5） 反響の少い防音聴力検查室では周波数の高い愉查 音に対する前後覚がやや良くなる傾问が正られた。

C Noise を検查音とした前後覚の研究

以上の研究上り複合音は前後が分りやすく，普通の研 究室でも，反響の少い防音室でむほぼ同様な成績が得ら れたので前後覚䃘究に適した検查音であることが分つ
た、ただし1〜2回音を聞かせるだけでは，まぐれ当り もあるので少くとも一種類音について 10 回前後の音を 聞か汭必要がある．また会話や楽音では持続時間を短 くすると一つ一つ性質の異つたものとなり，同一種類と はいえなくなるので，複合音で連続的に同じょうな音が 出て，から各周波数の音を含んでいる WN が適当と考 えられたので, 主としてこれを用い，さらにこれより各 種の音をつくつて研究を行つた. 以後の研究で検查の場 は特に明記しない場合, 険查 4 で述べた当教室防音聴力 検查室で行つた。

2）検査音の性質と前後覚

1) 持続時間之周波数成分

この二つは別々に取扱うべきものであるが，蚞笪はこ の二つを同時に変えて行つたものが多い，周波数成分を 变光ずに同一音を単に持続時間のみ変えて何回も聞か世 ると，被検者は前後の音の僅かの音色差（技術的に全く なくすことは至難である）を記憶し，これを手掛りとし て前後を答える恐れがあるので，每回異つた周波数成分 の音を出して記譩できぬようにする必要がありたためで ある. 检查は正中前後 $1.0 \mathrm{~m}$ 上り以下に示すごをき種頪 の音を SL 50db で順不同で聞かせた。

i) 1/2オクターブウ Band Noise（BN）で持続時 間 $0.1 \sim 0.5 \mathrm{sec}$ 音の場合（検査 5 )

WN よりオージオフイルターを用いて表1のごとき 各種 $1 / 2$ オクターブ巾 BN をつくり，持続時間 0.10 , 0.25 およ゙ $0.50 \mathrm{sec}$, 立上り立下り時間 $25 \mathrm{msec}$ として 20 32 才の正常人 5 名（81名 94 名）に2 回つつ聞 せた，得られた結果では持続時間 $0.10 \sim 0.50 \mathrm{sec}$ の間に は前後覚に特に差は認められなからたので一括して表1 示す。

$1 / 2$ オタターブ巾 BN に対する前後覚は WN K比 して䍐いが，他に與味深いことは $2400 \mathrm{cps}$ 以上の BN は前に定位されやすく特に $3400 \mathrm{cps}$ 以上の BN で前後 を諨つたるのは全部後からの音に対してであった。

表1 $1 / 2$ オターブウ BN に対する前後覚

\begin{tabular}{|c|c|c|c|c|c|}
\hline $\begin{array}{c}\mathrm{BN} \text { の成分 } \\
\mathrm{cps}\end{array}$ & $\begin{array}{l}\text { 前後の } \\
\text { 䛊扰よ } \\
\text { び不明 } \\
\text { の 数 } \\
\end{array}$ & $\begin{array}{l}\text { 前後の } \\
\text { 誤扣よ } \\
\text { び不明 } \\
\text { の } \%\end{array}$ & $\begin{array}{c}\text { BNの成分 } \\
\text { cps }\end{array}$ & $\begin{array}{l}\text { 前後の } \\
\text { 誤如よ } \\
\text { U゙不明 } \\
\text { D 数 } \\
\end{array}$ & 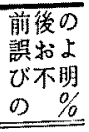 \\
\hline & 7 & 3 & & 9 & 300 \\
\hline & 4 & 13.3 & bo & 9 & 0. \\
\hline & 7 & 23.3 & 800 & 11 & 36.7 \\
\hline $200 \sim 1700$ & 5 & 16.7 & 4800 & 9 & 30. \\
\hline
\end{tabular}


ii） 1 オクターブ巾 BN で持続時閂 25 250 $\mathrm{msec}$ 音の場合（检查6)

表 2 のごときオークターブ巾 BN で持綕時間がそ れどれ 25, 50, $100,250 \mathrm{msec}$, 立上り立下り時閒 $5 \mathrm{msec}$ のすのをつくり，19〜40才の正常人10名（88名우 2
名）に前後より1回つつ聞かせて得られた成續を表 2 に 亦水.

1 オタターブ币 $\mathrm{BN}$ 25〜250msec 音に対する 前後覚 は一般に恶い，また 3400〜6800cps の BN を除き持続

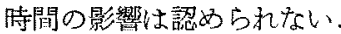

表 21 オクターブ巾 $\mathrm{BN} 25 \sim 250 \mathrm{msec}$ 音に刘する前後覚

\begin{tabular}{|c|c|c|c|c|c|c|c|c|c|}
\hline \multirow{2}{*}{$\begin{array}{c}\mathrm{BN} \text { 成分 } \\
\text { cps }\end{array}$} & \multirow{2}{*}{$\begin{array}{c}\text { 持続時間 } \\
\text { msec }\end{array}$} & 譔と不明 & \multicolumn{2}{|c|}{ 前後の䘫および } & \multirow{2}{*}{$\begin{array}{c}\text { BNの成分 } \\
\text { cps }\end{array}$} & \multirow{2}{*}{$\begin{array}{c}\text { 持続時間 } \\
\text { msec }\end{array}$} & 諰と不明 & \multicolumn{2}{|c|}{ 前後の椌㕲上び } \\
\hline & & & 本明 & 00 & & & & 不 日 & \\
\hline 425 & 25 & 9 & 45 & \multirow{4}{*}{46.2} & 1700 & 25 & 9 & 45 & \multirow{4}{*}{35.0} \\
\hline \multirow{2}{*}{$?$} & 50 & 12 & 60 & & \multirow{2}{*}{ l } & 50 & 7 & 35 & \\
\hline & 100 & 8 & 40 & & & 100 & 5 & 25 & \\
\hline 850 & 250 & 8 & 40 & & 3400 & 250 & 7 & 35 & \\
\hline 850 & 25 & 9 & 45 & \multirow{4}{*}{42.5} & \multirow{4}{*}{$\begin{array}{c}3400 \\
? \\
6800\end{array}$} & 25 & 10 & 50 & \multirow{4}{*}{35.0} \\
\hline \multirow{2}{*}{$?$} & 50 & 10 & 50 & & & 50 & 9 & 45 & \\
\hline & 100 & 8 & 40 & & & 100 & 6 & 30 & \\
\hline 1700 & 250 & 7 & 35 & & & 250 & 3 & 15 & \\
\hline
\end{tabular}

iii） 1 オクターブ巾 $\mathrm{BN}$ で持続時間 0.25

$2,5 \mathrm{sec}$ 音の場合（输查 7)

検查6で高音成分の多いBNで前後筧の良くなる㑯 向がみられたので，1200 cps 以上で1オタターブ巾 $\mathrm{BN}$ 孛多くつくり持続時間を $0.25,0.50,1.0,2.5 \mathrm{sec}$, 立上り 立下り時間 $25 \mathrm{msec}$ として $20 \sim 40$ 才の正常人 11 名（8
7 名ㅇ 4 名) について正中前後よりそれぞれ 1 回づつ聞 か犹た結果老表了に示す

以上梌查 6 の結果之合わせて1オクターブウ BN 25 msec 2.5 sec 音に対す万前後覚はあまり良くないこと が分かた。

表 31 オクターブ巾 $\mathrm{BN} 0.25 \sim 2.5 \mathrm{sec}$ 音に詨する前後觉

\begin{tabular}{|c|c|c|c|c|c|c|c|c|c|}
\hline $\begin{array}{c}\mathrm{BN} \text { 成分 } \\
\mathrm{cps}\end{array}$ & $\begin{array}{c}\text { 持続時間 } \\
\text { sec }\end{array}$ & $\begin{array}{l}\text { 誤と不明 } \\
\text { の 数 }\end{array}$ & \multicolumn{2}{|c|}{$\begin{array}{l}\text { 前後の謓および } \\
\text { 不明 } \%\end{array}$} & $\begin{array}{c}\text { BNの成分 } \\
\text { cps }\end{array}$ & $\begin{array}{c}\text { 持絖時間 } \\
\text { sec }\end{array}$ & $\begin{array}{l}\text { 䛺と不明 } \\
\text { の 数 }\end{array}$ & \multicolumn{2}{|c|}{$\begin{array}{l}\text { 前後の犃および } \\
\text { 不明の\% }\end{array}$} \\
\hline 1200 & 0.25 & 8 & 36.3 & \multirow{4}{*}{34.1} & \multirow{2}{*}{$2400 \sim 4800$} & 1.0 & 7 & 31.8 & 34,1 \\
\hline \multirow{2}{*}{$?$} & 0.5 & 8 & 36.3 & & & 2.5 & 7 & 31.8 & \\
\hline & 1.0 & 7 & 31.8 & & \multirow[t]{2}{*}{3400} & \multirow{2}{*}{0.25} & \multirow{2}{*}{$\begin{array}{l}7 \\
7\end{array}$} & \multirow{2}{*}{$\begin{array}{l}31.8 \\
31.8\end{array}$} & \multirow{4}{*}{29.6} \\
\hline 2400 & 2.5 & 7 & 31.8 & & & & & & \\
\hline 1700 & 0.25 & 8 & 36.3 & \multirow{4}{*}{33.} & \multirow{2}{*}{6800} & 1.0 & 6 & 27.2 & \\
\hline \multirow{3}{*}{$\begin{array}{c}? \\
3400\end{array}$} & 0.5 & 9 & 40.9 & & & 2.5 & 6 & 27.2 & \\
\hline & 1.0 & 8 & 36.3 & & \multirow{4}{*}{$\begin{array}{c}4800 \\
? \\
9600\end{array}$} & 0.25 & 9 & 40.9 & \\
\hline & 2.5 & 4 & 18.3 & & & 0.5 & 5 & 22.7 & 28.4 \\
\hline \multirow{2}{*}{$2400 \sim 4800$} & 0.25 & 8 & 36.3 & \multirow{2}{*}{34.1} & & 1.0 & 5 & 22.7 & \\
\hline & 0.5 & 8 & 36.3 & & & 2.5 & 6 & 27.2 & \\
\hline
\end{tabular}


iv）WN 括よび BN で周波数籍困 0〜850cps, $850 \sim 2400 \mathrm{cps}, 2400_{\mathrm{cps}} \sim$ の6ので持続持 間 $0.50 \mathrm{sec}$ の場合 (検查 8 )

1オクターブ巾よりさらに周波数籁囲を脑げ，持続時 間は今迄の検查であまり影響しないことが分つたので

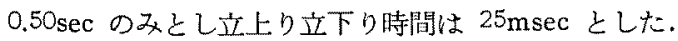
15 54 才の正常人 30 名( 19 名 911 名) について正中 前後より4回ぶ閐かせて得られた成績を表4に示す

表 4 WN 打よび周波数籍国の広い

$\mathrm{BN} 0.50 \mathrm{sec}$ 音に対する前後覚

\begin{tabular}{|c|c|c|c|c|}
\hline \multirow{2}{*}{ 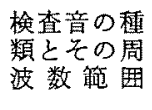 } & \multirow{2}{*}{$\mathrm{W} N$} & \multicolumn{2}{|r|}{ B } & $N$ \\
\hline & & $0 \sim 850$ & $850 \sim 2400$ & $2400 \sim$ \\
\hline $\begin{array}{l}\text { 前後を愦る } \\
\text { 数おむ゙不 } \\
\text { 明の 数 } \\
(240 \text { 音中) }\end{array}$ & 4 & 85 & 61 & 9 \\
\hline$\%$ & 1.7 & 35.4 & 25.4 & 3.7 \\
\hline
\end{tabular}

BN のゆが異るので一概にはいえないが，周波数成分 が高い程前後賞がよい、周波数範用の広いWN の前後 覚が一番よい。

v) WN および BN で周波数範囲 O〜3400 cps, $3400 \mathrm{cps} \sim$ のむので持続時間 $1.0 \mathrm{sec}$ の場合 (梌查 9)

立上り立下り時間を $25 \mathrm{msec} と し$ 項目のごとき音をそ れぞれ前後上り5回づつ18〜34才の正常人5名（81 名果 4 名) に聞加世大結果を表5 に示才

BN $3400 \mathrm{cps} \sim$ は BN O〜3400cps に比して前後がつ゚

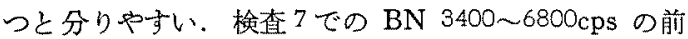
後覚と異るのは周波数成分の違いにもよるが, 検查 7で は定位し難い1つつつ異つた周波数成分の BNばかり

表 5 WN 和よび周波数範囲の広い

$\mathrm{BN} 1.0 \mathrm{sec}$ 音に対する前後覚

\begin{tabular}{|c|c|c|c|c|c|c|}
\hline \multirow{3}{*}{$\begin{array}{l}\text { 検査音の種 } \\
\text { 類とその周 } \\
\text { 波数範囲 }\end{array}$} & \multirow{2}{*}{ W } & \multirow{2}{*}{$\mathrm{N}$} & & B & \multicolumn{2}{|c|}{$\mathrm{N}$} \\
\hline & & & \multicolumn{2}{|c|}{$0 \sim 3400 \mathrm{cps}$} & \multicolumn{2}{|c|}{$3400 \mathrm{cps} \sim$} \\
\hline & 前 & 後 & 前 & 後 & 前 & 後 \\
\hline $\begin{array}{l}\text { 前後定誤る } \\
\text { 数之不明の } \\
\text { 数 (25音中) }\end{array}$ & 0 & 1 & 15 & 0 & 0 & 3 \\
\hline $\begin{array}{l}\text { 前後の唄り } \\
\text { と明の\% }\end{array}$ & \multicolumn{2}{|c|}{2.0} & \multicolumn{2}{|c|}{30.0} & \multicolumn{2}{|c|}{6.0} \\
\hline
\end{tabular}

を前後より1回づつしか聞かせなかつたのに反して，检 查9では間に入る音が WN で定位しやすくこれと比較 でき，しかも一種類につき前後より5回づつ聞がたた めと考えられる，また検査 5 と同じく低い $\mathrm{BN}$ は後， 高い $\mathrm{BN}$ は前と答光や产い傾向がみられる。

vi）WNより周波数成分を一部抜いた音で持続時間 $0.50 \mathrm{sec}$ の場合（検查 10 )

検査 5〜9では WN の両端を周波数カットして BN をつくつたのであるが，今度はWN の中の周波数成分 を一部除いた音で前後觉をしらべた。

拔いた音のウは $1 / 2$ 拉よび 1 オークターブ巾で表6の ごとくその中心周波数を半オクターブづつ变亲て各々に つき9種の異つた音を得た（これらの音群を今後便宜上 $1 / 2$ 扎よび 1 オクターブウ欠 WN と呼称する).

表 6 WNより技いた欠周波数範围 (cps)

\begin{tabular}{|c|c|c|c|c|c|}
\hline \multicolumn{3}{|c|}{$1 / 2$ オターブ巾 } & \multicolumn{3}{|c|}{1 オクターブ巾 } \\
\hline 425 & $\sim$ & 600 & 300 & $\sim$ & 600 \\
\hline 600 & $\sim$ & 850 & 425 & $\sim$ & 850 \\
\hline 850 & $\sim$ & 1200 & 600 & $\sim$ & 1200 \\
\hline 1200 & $\sim$ & 1700 & 850 & $\sim$ & 1700 \\
\hline 1700 & $\sim$ & 2400 & 1200 & $\sim$ & 2400 \\
\hline 2400 & $\sim$ & 3400 & 1700 & $\sim$ & 3400 \\
\hline 3400 & $\sim$ & 4800 & 2400 & $\sim$ & 4800 \\
\hline 4800 & $\sim$ & 6800 & 3400 & $\sim$ & 6800 \\
\hline 6800 & $\sim$ & 9600 & 4800 & $\sim$ & 9600 \\
\hline
\end{tabular}

持続時間 $0.50 \mathrm{sec}$ 立上り立下り時間 $25 \mathrm{msec}$ とし, 前後より1回づつ順不同で閙かせた。被検者は30〜60 才の正常人 25 名（各15名早10名）で1/2ついで1才ク ターブウ欠 WN の順に検査を行つた．結果は図4のご とくで，WN と同様に前後はよく弁別されることを示 している。また欠周波数带の周波数による違いも殆んど みられない

图 $41 / 2$ (実線) および1 (点線) オクターブ 巾欠 WN $0.50 \mathrm{sec}$ 音に対する前後覚

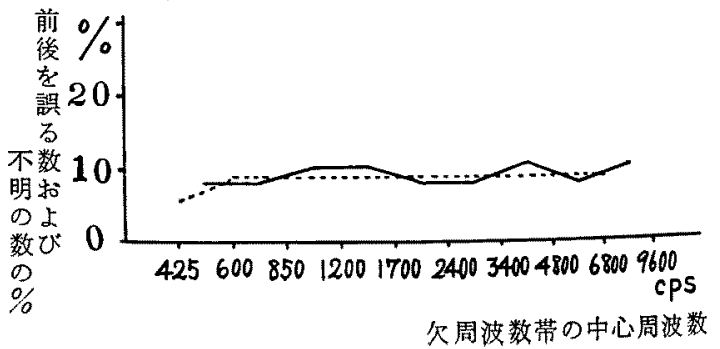


これらの被検者は高令者を含めたためか純音閂值は正 常であるが，前後覚不良の人が 3 名 $(12.5 \%)$ 含玉れて いて検査音の $50 \%$ 以上前後を誤るか不明であつた。 そ の他の人は殆んどが全音を正しく定位し，誤つた人でも 18音中2音以内を愦つたに過ぎない，すなわち大をく

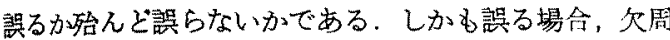
波数帯の周波数成分の違いによる影響は殆んどみられな いそ省でこの9種の 1/2オクターブ巾欠 WNを一括 して一つの検查音とみなし前後覚をしらべれぱ，前述の ごとく正常者と異常者とで大きく差がつく上に各々少し づつ音色が異つているので検查音として最適なるのであ ると考えられた。

vii） $1 / 2$ オクタープ巾欠 WN で持続時開が 25〜 $500 \mathrm{msec}$ の場合（検査 11 )

1/2オクターブ巾欠 WN が検査音として適当なこと が分つたが，高音成分がいろいろ变ることは好ましくな いと考交られたので，久周波数寡の上限を $2400 \mathrm{cps}$ と まりとして5 種類の音を用い持続時問を $25,50,100$, $250,500 \mathrm{msec}$ ，立上り立下り時間を $5 \mathrm{msec} と し ，$ 正中 前後より1回づの $\mathrm{SL} 30 \mathrm{db}$ で聞かせた．被湌者は 18 〜64 才の正常人 8 名 (万4 名早 4 名) で得られた結果を 因5 示寸，50 m みられた。

図51/2オクターブ币欠 WN の持繶時間 を变占た場合の前後覚

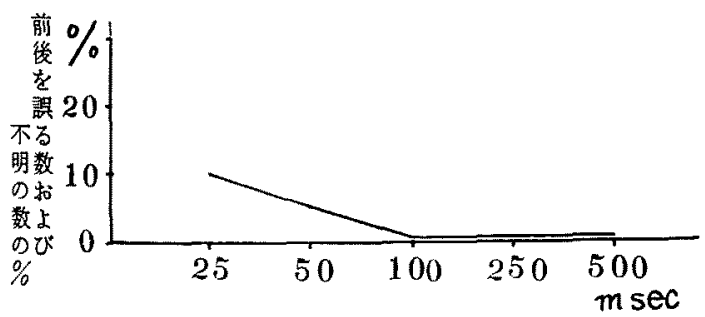

持続時間

2）立上り立下り時間の影響について（検査 12）

検查音は検查 11 で用いた $1 / 2$ オクターブ巾欠 WN で持続時間 $250 \mathrm{msec}$ ，立上り立下り時間を $5 ， 10 ， 25$ ， $50,100 \mathrm{msec}$ とし，それそれ 10音づつ20５8才の正常 人 5 名（32名早 3 名）について正中前後 $1.0 \mathrm{~m}$ 上り SL 30dbで聞かせた，得られた結果は图6のごとくで 迆り立下り時間は殆九ど影響しない。上つて検查 13 以下の研究では検査音の立上り立下り時間を $25 \mathrm{msec}$
图 $61 / 2$ オタターブ巾久 WN の立上り立下り 㭙間を变えた場合の前後觉

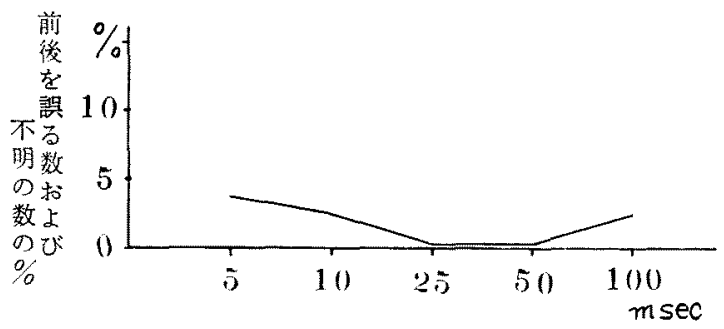

立上り主下り時間

のみとした。

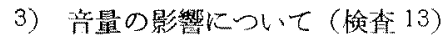

榆查音は检盗 11 と同じ 1/2オタターブ巾欠 WNで 持繶時閒 $0.50 \mathrm{sec} と し$ ，关の強さを SL 20,30,40,50， $60 \mathrm{db}$ とし，この順で各 $\mathrm{db}$ につき10音づっ 19〜52 才

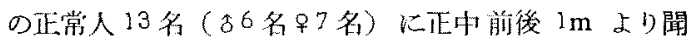
かせた。経果は図7のこととく SL 30db より小さいと前 後覚に影響がみられるが 40db 以上では音量に関係なく 前後覚は良い。

图 7 1/2オクターブ巾火 WN の踽さを 学之た䭪合の前後営

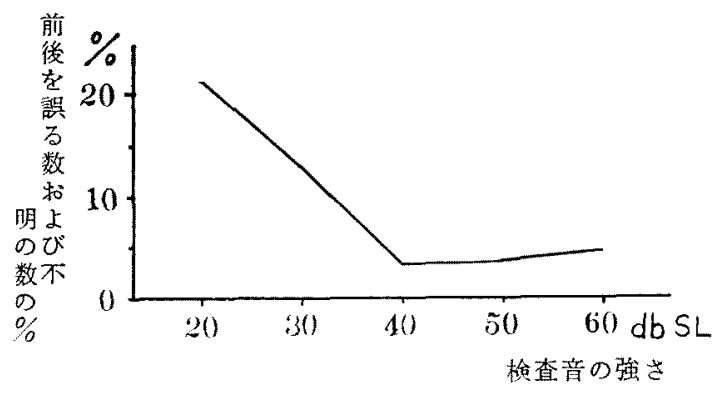

さらに前後を誤る数でなく人数別に前後覚を分けてみ ると，13名中检查音量 $20 \mathrm{db}$ ですでに良い前後覚を示 すもの7名，20db 上り音量を大にするにつれて前後覚 の良くなるbの5名，案量に関係なく前後の手别が全く できないもの1名であつた。このよ5に正常人と思われ るものの中に前後筧不良都が存在することは检查 10 で も述べた。

4）音源の位置について

音源の位置については上下左右方向の他，被検者との 距離も問題であるが，それぞれについて詳しくしらべる 余裕か゚ないので本研究では距離は $1.0 \mathrm{~m}$, 上下は被検者 の耳の高さとし，正中和よび正中より何度か左右へ奇つ 
た音源位置についての前後覚を研究した．以後音の方角 は正面を $0^{\circ}$ とし右廻りに何度と表わすことにする．正 中上り左右へ寄つた方角の音は図 1 b- $b^{\prime}$ または $c-c^{\prime}$ のごとき配置で聞かせた。

i) $45^{\circ}-135^{\circ}$ (右前一右後) 扣上び $315^{\circ}-225^{\circ}$ (左 前一左後) 音の場合（検查 14）

正中面より左右へ寄つた位置にある音源の場合で， $45^{\circ}$ と $135^{\circ}$ の二方 向音の弁別 扒よび $315^{\circ}$ と $225^{\circ}$ 万向

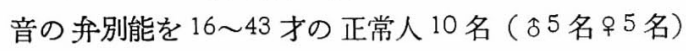
についてしらべた。検査音は検査8で用いたものと同じ $\mathrm{WN}$ と BN 3 種類の 8 ケづつで $0^{\circ}-180^{\circ}$ 音, $45^{\circ}$ $135^{\circ}$ 音, $315^{\circ}$-2250音の順で SL $50 \mathrm{db}$ で聞かせた結 果前後を誤る数と不明の数の\%は表 7 のごとくなる.

表 7 音源の方角を变えた場合の 前後を誤る数と不明の数\%

\begin{tabular}{|c|c|c|c|c|c|c|}
\hline & 本 & & & & B & $\mathrm{N}$ \\
\hline $\begin{array}{l}\text { 音源 } \\
\text { の方角 }\end{array}$ & & 数範团 & WN & $\begin{array}{r}\text { cps } \\
0 \sim 850\end{array}$ & \begin{tabular}{|r|}
$\mathrm{cps}$ \\
$850 \sim 2400$
\end{tabular} & $2400 \sim$ \\
\hline $0^{\circ}$ & - & $180^{\circ}$ & 1.3 & 36.3 & 31.2 & 6.3 \\
\hline $45^{\circ}$ & - & $135^{\circ}$ & 1.3 & 22.5 & 10.0 & 2.5 \\
\hline $315^{\circ}$ & - & $225^{\circ}$ & 0 & 16.3 & 12.5 & 3.8 \\
\hline
\end{tabular}

表 7 から正中音より左右へ $45^{\circ}$ 寄つた方角音の方が前 後の众別がしやすいことが分る.

ii）正中面より側方へ $15^{\circ}$ づ音源位置を変えた 場合 (検査 15)

装置の都合で検査室は普通の静かな洋室である，その ほぼ中央で $2.2 \times 2.5 \times 2.4 \mathrm{~m}$ の空間を厚いカテーンで囲 んで一つの場をつくり，写真 1 亿示すごとくこの場の中 心を軸として 2 本の支柱が天井に沿つて回るようにして ある. この支柱の中心から $1.0 \mathrm{~m}$ 離れた所から腕木が下 りて丁度被検者の耳の高さでスピーカーが中心向くよ らに取りつけてある. 中央衹被検者を座らせ, 正中前後

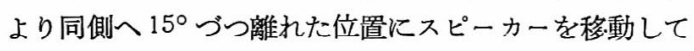
それぞれの位置での前後覚をしらべた。

聞かせた音は $1 / 2$ オクターブ巾欠 WN 9 種 18 音で SL 50db で鳴らした. 検査対象は聴力正常であるにも 拘らず正中前後音の弁別の悪い 2 人である（普通の正常 人では正中前後覚が良く，左右へ寄つた方向音ではさら に良くなるので本研究には向かない)，得られた結果は 図8のごとくで，偏倚度 $15^{\circ}$ では $0^{\circ}$ と同じであるが， $30^{\circ} 45^{\circ}$ では前後覚は良くなる，600では 1 例はよいが

\section{写 真 1}

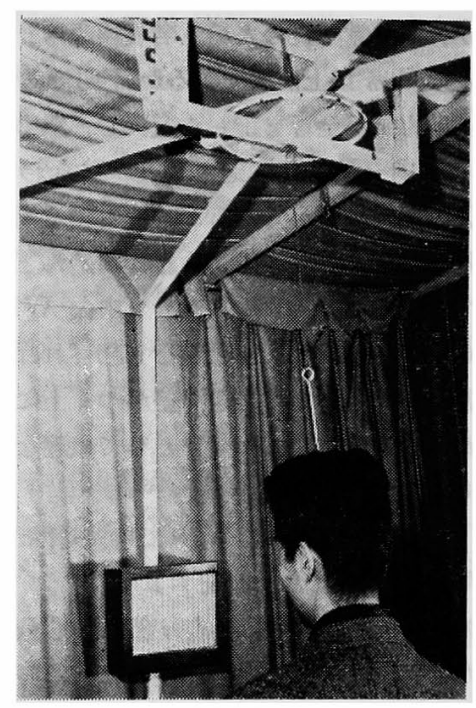

図 8 音源の方角を変光た場合の $1 / 2$ オクターブウ欠 WN に対する前後覚

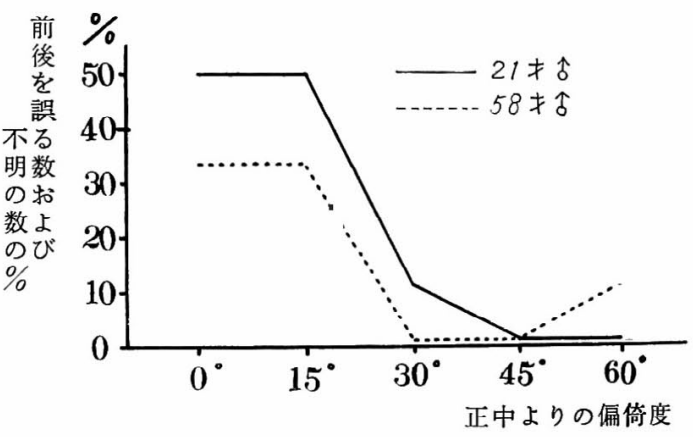

他の 1 例ではやや不良である.ささらに 600をこ学ると前 後感より横といら感が強く前後の弁別は別の意味で難か しくなる.

5) 小 括

1) 15 64 才の正常人総数 124 名（370名우 54 名） について検査音の性質が前後覚にいかに影響するかにつ いて WN, BN および WN の周波数成分を一部抜い た音を用いてしらべた.

2）音の周波数成分の範囲が狭くなる程前後の弁別は 難かしくなる，乙かし周波数範用が広くても高音成分が 欠けていると弁別し難い.

3）WN の中に $1 / 2$ または1オクターブ巾の欠周波 数帯をつくつた検査音ではその抜いた周波数泡らず前 後覚は一般に極めて良いが，ごく一部の人では両衈力 
正常に抱らず前後覚不良であつた。

4) 高い䧓波数成分の BN は前に定位されや可い

5) WN および $1 / 2$ オターブ币欠 WNでは持続 時間が 25 50 msec の时は多少前後覚のわるくなる人 が認められたが，100 msec 以上では前後覚は良好であつ t.

6) 1/2オクターブ巾欠WN 250msec 望に対して立 上り立下り時間を $5 \sim 100 \mathrm{msec}$ と变えても特に前後筧 に著差は認められなかつた。

7) $1 / 2$ オクターブウ欠 WN $0.50 \mathrm{sec}$ 音の音冒を咬

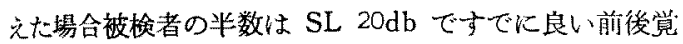
を示すが、のこりの半数は SL $40 \mathrm{db}$ 以上で良い前後筧 宗した。

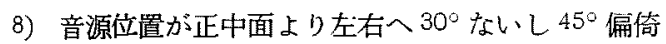
している時の万が前後音の告別がしやすい。

9) 以上の結果か、前後覚検查音として持続時間 100 $\mathrm{msec}$ 以上，強さ SL $40 \mathrm{db}$ 以上，立上り立下り畤間 $25 \sim 50 \mathrm{msec}$ の WN および1/2ナタターブ巾欠 WN が最適と考光られた。

b 被検者僛の条件

1) 性别について

蚞查1 24に执いて正常人男于 195 名女子120名につ いてしらぺたが特に性による前後覚の違いは認めなかつ t.

2）年令について（検租 16）

本検查は自党的娭香法であるので奻胃では充分正磼な 返答は期待し難く 注意力も長続きせす飽きやすい、む た検査中に賈を動かさない上らに注意しても仲々守ら机 難い，それに反して健康老令者や学童では前か後かを答 えるたりげ特に思考を要する検查法ではないから充分検 督を行い得た。

尔令が增与につれて動脈硬化その他の老人性嶨化が扰

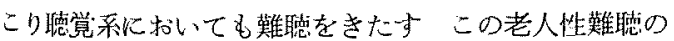

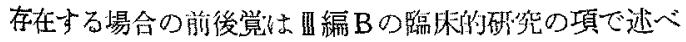
るが，年をとつていても若い人と同じ維音聴力を有する 人を壂んで前後覚を若い人と比べてみた場合にもやはり

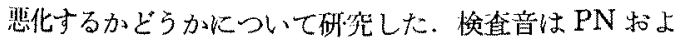
び険查8で用いたのと同じ WN と BN 3 種計 5 種類 の $0.50 \mathrm{sec}$ 音でそれでれ正中前後より8音つ゚つ16才。 54 才の正常人 30 名（819名％11名）について聞力世 たこの30を年命的に 10 名づつ3群に分けてをの前後 愦る数と不明の数の\%をしらべたとこる㳖 8 のごとく なる.
表 8 年令別による前後覚

(前媵を器る数と不明の数\%)

\begin{tabular}{|c|c|c|c|c|c|c|c|}
\hline \multirow{2}{*}{\multicolumn{3}{|c|}{ 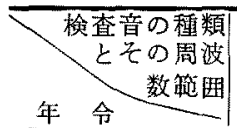 }} & \multirow{2}{*}{$\mathrm{PN}$} & \multirow{2}{*}{ WN } & \\
\hline & & & & & $\begin{array}{r}\mathrm{cps} \mid \\
0 \sim 850\end{array}$ & $\begin{array}{r}0 \quad \mathrm{cp} \\
\sim 240 \\
\end{array}$ & $\begin{array}{r}c \\
100\end{array}$ \\
\hline 16 & & $30 才$ & 13.8 & 1.3 & 36.3 & 26 & 5.0 \\
\hline 31 & $\sim$ & $40 才$ & 10.0 & 0 & 36.3 & 22.5 & \\
\hline 41 & & 54 才 & 8.8 & 3.8 & 33.8 & 26.3 & 6.5 \\
\hline
\end{tabular}

殆んどの人が前後を正しく弁別しらるWN和よび BN 2400〜 の音の両方共前後党のわるい人（49才。） が一人いて，このため 41〜54 才辞の成續がわるくなつ ている，その他の人楉年群上殆んど同じ前後賞を示し た、結局若年者と此して同じ正常聴力を有する壮年〜老 令者の前後覚は一般に同程度といえるが，前後覚不良者 が正常聴力者の中に見出される咄能性は年令が高い程多 いのではないかと考えられる。

3) 頭部連動の影䅧について

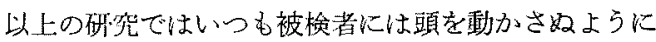
指示し，他覚们に顛が動いているように見えだ時は検查 を一旦中止し注意を与えた後䋉行した，その理由は検査

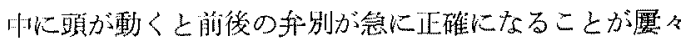
認められたからである。そこで被検者の皟の運動の前後 覚へおよぼす影製を研究した。

i）頭部を被険者自身で回眩した時の前徭覚 (榆查 17)

被换者には予め閉眼で頭を自分で動かさぬよらに指示 して前後筧をしらぺ，ついで同じ音を聞かせ今度は音が 鳴ると同時に䫓を水平面内で $5^{\circ}$ ます上うにさせて （䫒を壁の一点からスピーカをはさんで50はなれた他の 一点へ向けさ世る）前後覚をしらベた，检查音は頭の運 䣦の效果がよく現れるように頭部静止時には前倦の弁 别のしにくい1オクターブ巾 BN 5 種を潠び持続時間 $0.50 \mathrm{sec}$ とし，こ扎ら老四中㓩後より $28 \sim 40$ 才の正常人

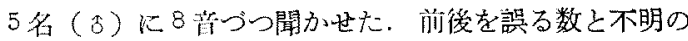
数の\%表 9 に亦す

表 9 频部回埲時の $\mathrm{BN}$ に刘与る前後觉 (前後を誤る数と不朋の数の\%)

\begin{tabular}{|c|c|c|c|c|c|}
\hline 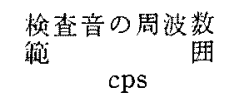 & $\begin{array}{c}1200 \\
? \\
2400\end{array}$ & $\begin{array}{c}1700 \\
? \\
3400\end{array}$ & $\begin{array}{c}2400 \\
? \\
4800\end{array}$ & $\begin{array}{c}3400 \\
? \\
6800\end{array}$ & $\begin{array}{c}4800 \\
l \\
9600\end{array}$ \\
\hline 頭部筝 止㭙 & 35.0 & 32.5 & 42.5 & 32.5 & 35.0 \\
\hline 㑔部 $5^{\circ}$ 回枟㭙 & 12.5 & 7.5 & 5.0 & 0 & 2.5 \\
\hline
\end{tabular}


䫂部迴転時には前後覚が良くなり，しかも高い周波数 になる程その効果は大である.

ii）レシーバー装着法による頭部廻転の影響 (検査 18)

検査 14,15 で音源が正中面より左右へ寄つた時は前後 の弁別がしやすいことを示したが，このことから頭を動 かすと前後覚の良くなるのは運動の効果ではなくて単に 斜横をむいている状態すなわち正中でない斜からの音を 聞くために前後覚がよいのであるとも若えられるので, 耳介効果の無いしかも頭の陰影効果の少い状態をつくつ て頭部迴伝の前後覚に及ぼす影響をしらべた。

検査音は $\mathrm{PN}, \mathrm{WN}$ および $\mathrm{BN}$ の周波数成分が 0 〜 $3400 \mathrm{cps}, 3400 \mathrm{cps} \sim$ のもの 2 種計 4 種類 10 音つつで持

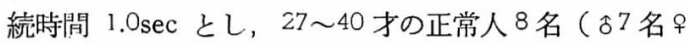
1名）の正中前後より聞かせた。被検者は両側頭部にマ イクロホン(ソニー FP-2 型)を上向きにつけている. その出力を 2 チヤンネルの增巾器 (LUX PZ 21 型) を 通し，途中で接続を逆にして被検者の両耳に当てたレシ ーバーに導く、すなわら右のマイクから音は左耳に, 左 のマイクのは右耳に入るようにしてある.

接続を逆にしたのはレシーバーと耳の接着の悪い人で は音がこの方きまから直接耳に入り，それで前後を判断 するという可能性を除くためである．こうすると正常人 では前からの音は後に，後の音は前に聞えるので，検査 に際し前後を逆に答えたものを正答とし，それ以外は前 後を誤つたものとして取扱つた.レシーバーから実際に 耳に入る音量は SL $50 \mathrm{db}$ となるようにしてある．検査 は始め頭を静止させた状態で前後筧をしらべ，ついで音 が鳴り出すと同時に検査 17 と同様に頭を 50 まわした場 合の前後覚をしらべた. 前後を誤る数と不明の数の\%は 表10のごとくで，頭部回転により前後覚は確かに良く なる

表 10 で韻部静止侍の前後を 誤る数と不明の数が $50 \%$ を越えているのは前後を逆に（つまり金際の音源を正し く）答えているのではなくて，本法のごとくレシーパー

表 10 レシーバー装着時の頭部回枟による前後觉 （前後を誤る数と不明の数の\%)

\begin{tabular}{|c|c|c|c|c|}
\hline \multirow{2}{*}{$\begin{array}{l}\text { 検査音の種類と } \\
\text { その周波数範田 }\end{array}$} & \multirow{2}{*}{ PN } & \multirow{2}{*}{ WN } & B & $\mathrm{N}$ \\
\hline & & & \begin{tabular}{|c|} 
cps \\
$0 \sim 3400$
\end{tabular} & $3400 \sim$ \\
\hline 頭部静止侍 & 53.7 & 66.1 & 67.4 & 65.0 \\
\hline 須部 $5^{\circ}$ 回㕬時 & 30.0 & 22.5 & 18.5 & 18.5 \\
\hline
\end{tabular}

使用時は音は頭蓋内に聞えるので前後不明といら答が多 くなるためである．

iii）電動椅子による廻転時の前後覚（検査 19）

検査 17,18 の方法では被検者の頭の動かし方に上手下 手ができるので, 電動椅子にて被検者の頭をその体ごと 一定の速さで回転させた場合の前後覚に及ぼす影響をみ た.

写真 2 電動式振子様回転榆子

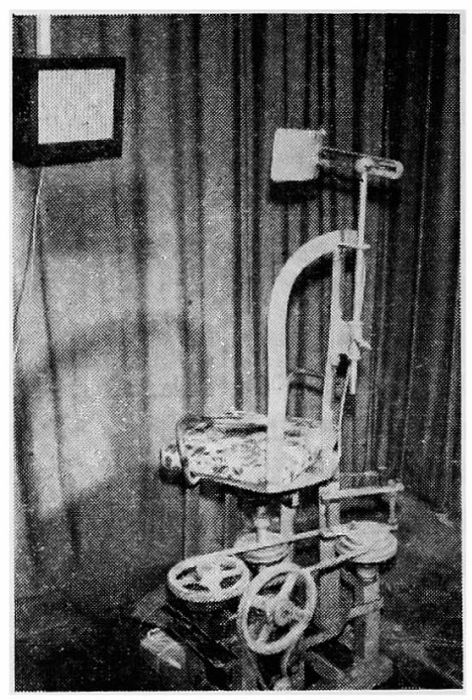

検査 15 と同じ室で 中央に写真 2 に示すごとき電動式 振子様回転椅子があり, その前後 $1 \mathrm{~m}$ の所にスピーカ 一が取りつけられてある. 回転㥓子が前のスピーカーの 方を向いた時にトリガーのスイッチが入つて電子スイッ チが働き, 表11 のごとき $1 / 2$ オクターブ巾 BN が持続 時間 $0.05,0.10,0.25,0.50 \mathrm{sec}$, 立上り立下り時間 10 msec SL $50 \mathrm{db}$ で出てくるよらにした. 被検者は18〜 30 才の正常人 8 名 ( 81 名 97 名) で電斬椅子に座り, 頭は椅子の背の支柱に固定されている. 電動㥓子の回転 の周期は $5.0 \mathrm{sec}$ で振巾は $90^{\circ}, 60^{\circ}, 30^{\circ}$ の 3 通りで検 査はこの順で行つた．前記検査音を 2 回づつ前後より 8 名に聞かした時の前後を誤る数の\%は表 11 のごとくな る.本成績とみるとパラッキが比較的大きいが，一般に 認められる傾向として，1）静止時（検査 5) と比較し て回転時の前後覚はずつと良い，2）BN の成分周波数 が高い程回転時の 前後覚は良くなる．3）回転速度が同 じなら音の鳴つている時間の長い程（振れの角度の大き い程）前後覚は良い，4）音の鳴る時間が同一であれぱ 回転速度が早い程前後覚は良い，5）同じ角度だけ回転 
表 11 電動笨子による回枟時の前後觉

\begin{tabular}{|c|c|c|c|c|}
\hline \multirow{2}{*}{$\begin{array}{c}\text { BNの周 } \\
\text { 波数範国 } \\
\text { cps }\end{array}$} & \multirow{2}{*}{ 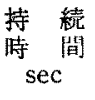 } & \multicolumn{3}{|c|}{ 前後を䛊る数と不明の数の\% } \\
\hline & & 振内 $90^{\circ}$ & 振们 $60^{\circ}$ & 振门 $30^{\circ}$ \\
\hline 425 & 0.05 & 56.2 & 62.5 & 56.2 \\
\hline \multirow{2}{*}{ ? } & 0.10 & 25.0 & 50.0 & 25.0 \\
\hline & 0.25 & 18.8 & 25.0 & 37.5 \\
\hline 600 & 0.50 & 6.3 & 18.8 & 12.5 \\
\hline 850 & 0.05 & 31.2 & 31.2 & 37.5 \\
\hline \multirow{2}{*}{ ? } & 0.10 & 25.0 & 18.8 & 31.2 \\
\hline & 0.25 & 6.3 & 6.3 & 37.5 \\
\hline 1200 & 0.50 & 6.3 & 6.3 & 18.8 \\
\hline 1700 & 0.05 & 25.0 & 12.5 & 37.5 \\
\hline \multirow{2}{*}{$?$} & 0.10 & 50.0 & 18.8 & 25.0 \\
\hline & 0.25 & 12.5 & 12.5 & 25.0 \\
\hline 2400 & 0.50 & 0 & 6.3 & 12.5 \\
\hline 3400 & 0.05 & 43.7 & 25.0 & 18.8 \\
\hline \multirow{2}{*}{ ? } & 0.10 & 25.0 & 18.8 & 18.8 \\
\hline & 0.25 & 0 & 6.3 & 0 \\
\hline 4800 & 0.50 & 0 & 0 & 0 \\
\hline
\end{tabular}

主る場合は成分䖝波数の高いBN において早く廹つて 䍄く聞くょりも，ゆつくり迴つて長く聞く方が前後覚が 泉い。

一般に被険者自らが頭を動か寸場台に比して定位がむ つかしいように思われた。これは被検者自らが蹎だけぬ わすといらのと椅子にのつて頭を体ごとまわすという違 いの他に，モーターその他の菱琶による騷音の存在を考 慮する必要があるかも知れない。

iv）被検者が顥部を自ら動かざようにした場合と 頭部㕝支柱へ固定した場合の前後賞（㭘査 20） 以上の砸究で頭部が動いていると前後賞は良くなるこ とが分つた，检查16迄の研究では被檢者が自ら頭部を 動かさぬように努力した状態での前後覚をしらべてきた のであるが，この状態では頭部の運動の要素がスつてい るのかいないのか分らないので，それをしらべるために 被検者の頍をしつかりと支柱に固定した場合の前後覚を しらべた．固定法は椅子の背につけた支柱に枕をあて巾 $8 \mathrm{~cm}$ のゴムバンドで影をしつかりとくくりつけた。検 查音は $\mathrm{PN}, \mathrm{WN}$ 扎よび $\mathrm{BN} 3$ 種計 5 種類 $0.25 \mathrm{sec}$ 音 でこれを正中前後より 5 回づす SL $50 \mathrm{db}$ で 27 40才 の罍力正常な，かつ前後覚検查に留熟した当教室員 4 名 （るのみ）に聞かせた。検㚗はまづ被検者が自分で頭を
表 12 斯部固定時の前媵觉

（前後を誤る数と不明の数の\%)

\begin{tabular}{|c|c|c|c|c|c|}
\hline \multirow{2}{*}{ 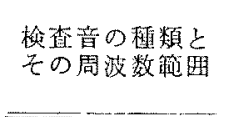 } & \multirow{2}{*}{$\mathrm{PN}$} & \multirow{2}{*}{ WN } & \multicolumn{3}{|c|}{ B $\quad N$} \\
\hline & & & $\begin{array}{r}c p s \\
0 \sim 850\end{array}$ & $\begin{array}{r}50 \text { cps } \\
\sim 1700\end{array}$ & $\begin{array}{r}\mathrm{cps} \\
1700 \sim \\
\end{array}$ \\
\hline 自ら解止した坦合 & 12.5 & 2.5 & 37.5 & 22.5 & 2.5 \\
\hline $\begin{array}{l}\text { 支柱一固定した } \\
\text { 場 }\end{array}$ & 5.0 & 2.5 & 30.0 & 22.5 & 7.5 \\
\hline
\end{tabular}

動かぬようにしている状態で行い、ついで頭を固定した 状態で行つた，前後を誤る数の\%は表 12 のごとくで凷 者の閻には箸差を認めなかつた。

\section{4) 耳栓菩着の影響}

今迄の研究で音音成分のない音は前啳の弁別が難かし いことを示したが，音の高音成分を被挨者側で人為的に カットした場合の前後覚をしらべた。

i）防音プラグおよび円筒による高音遮赎の場合 (检查 21 )

用いた耳柽は恩地式防音ブラグでその遮音度を哭際の 検直の場で測定してみると図9点線の上らになる。別に プラスチックで直惩 $10 \mathrm{~cm}$ 樑さ $7 \mathrm{~cm}$ の円筒様のもの をつくりこれる写真了に示すごとく被梌者の耳䎲 ら寸つぽりとかぶせて高音遮轑を行つた。この時の遮音 度は図9破線で示す。こ机らを被梌者の雨耳荘着し， 娭查音として PN, WN，扣上び BN $0 \sim 3400 \mathrm{cps}, \mathrm{BN}$ 3400 cps の計 4 種を10音つつ前後より正常人 5 名(

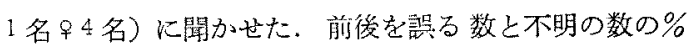
は表13のごとくで裸耳に比していつれの場合も前後覚 が覀化する。な拈 BN O 3400cps は後に BN $3400 \mathrm{cps}$ 〜は前に定位されやすい傾同がスられた。

図 9 防音プラグおよび円简の遮音度

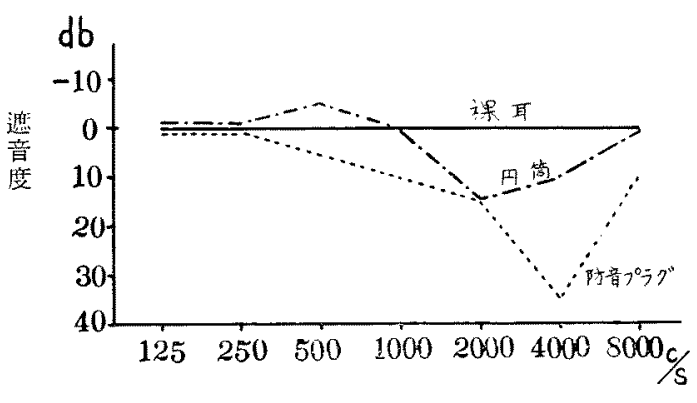


表 13 耳栓ならびに円简装着侍の前後筧 （前後を誤る数と不明の数の\%)

\begin{tabular}{|c|c|c|c|c|}
\hline \multirow{2}{*}{$\begin{array}{l}\text { 検査音の種類と } \\
\text { 周波数簬 囲 }\end{array}$} & & & B & $\mathrm{N}$ \\
\hline & $\mathrm{PN}$ & $W N$ & $\mid \begin{array}{r}\mathrm{cps} \\
0 \sim 3400\end{array}$ & $3400 \sim$ \\
\hline 裸 & 12.0 & 2.0 & 30.0 & 6.0 \\
\hline 耳 & 48.0 & 20.0 & 42.0 & 28.0 \\
\hline 両耳 円 筒 & 38.0 & 24.0 & 40.0 & 22.0 \\
\hline
\end{tabular}

写真 3 高音遮蔽用円筒の装着

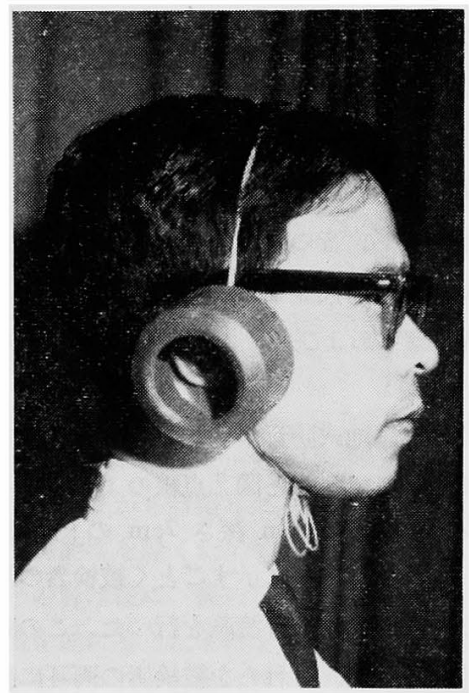

ii）耳栓装着耳と音源の方角との関係（娭查 22）

検查 21 で耳栓の効果は WN において著明であるこ とが分つたので，1/2オクタープ巾欠 WN 9 種（唡査 10参照）を前後より 1 回づつ聞かせ，音源位置と耳栓装 着側をいろいる変えた場合の前後覚をしらべた，検査音 はSL 50dbで聞かせ，用いた耳栓は検查 21 と同じも のである. 被恰者は19０1 才の正常人延 45 名（人14名

表 14 耳栓による前後営の恶化

\begin{tabular}{|c|c|c|c|c|c|c|}
\hline \multirow{2}{*}{$\begin{array}{l}\text { 音渻の } \\
\text { 方角 }\end{array}$} & \multirow{2}{*}{$\begin{array}{l}\text { 耳 栓 } \\
\text { 装着㑡 }\end{array}$} & \multirow{2}{*}{$\begin{array}{l}\text { 被众者 } \\
\text { 人数 }\end{array}$} & \multicolumn{4}{|c|}{ 耳恮效果の認められる数 } \\
\hline & & & $H$ & + & \pm & - \\
\hline \multirow{2}{*}{$0-180^{\circ}$} & 両 側 & 18 & 6 & 7 & 0 & 5 \\
\hline & 1 側 & 5 & 0 & 1 & 0 & 4 \\
\hline $30^{\circ}-150^{\circ}$ & 両 側 & 6 & 5 & 1 & 0 & 0 \\
\hline または & 近耳側 & 10 & 5 & 5 & 0 & 0 \\
\hline $330^{\circ}-$ & 違耳側 & 10 & 3 & 0 & 1 & 6 \\
\hline
\end{tabular}

999名) で両裸耳で検査音 18 音を全部正しく前後弁別 のできるもののみを選んだ，得られた結果を表 14 亿示 す

耳栓の効果は全く前後覚に变化を扣よぼさない場合を （一）とし，18音中 1 ヶの前後を誤つたものを（士），2 〜4 ケ誤るものを（十），5 ケ以上誤るものを（H）とし た．表の中で正中前後音に対して片耳栓の場合の 5 例は いられれ両耳栓時には前後覚の悪化 $(+\sim H)$ するもの のみを選んだ.

以上両耳耳烃装着時に正中音に対し $2 / 3$ 例 $3330-150^{\circ}$ $\left(330^{\circ}-210^{\circ}\right)$ 音に対しては全例前後覚が悪化し，片耳 耳桎装着時は正中前後音に 対しては殆んぞ影響がない が, $30-150^{\circ}\left(330^{\circ}-210^{\circ}\right)$ 音に対しては音源に近い方 の耳にのみ耳栓を装着すると全例前後覚が悪化し, 遠い 方の耳に装着した場合は $1 / 3$ 例が悪化した：

iii）両耳耳柽装着時の検査音の強さと前後覚との 関係 (恰査 23)

正中前後音に対して 裸耳にて前後覚良好な20６4 才 の9名（す5 名우 4 名）に兩耳に防音プラグを装着させ 前後覚をしらべた。検査音は $1 / 2$ オクターブ巾欠 WN で SL 20,30,40,50,60db の強さで 10 音づつ被検被 検者の正中前後より聞かせた.

結果は9 名中唡查音が SL $20 \mathrm{db}$ ですでに前後覚良好 のもの3 名, 検査音量を大にするにつれて良くなるもの 3 名で,のこり3名は音量に関係なく前後覚不良を示し た.

以上の検査で耳栓による影響が一応判明したが, 耳栓 により前後覚が変化しない人は果して耳栓が外耳道に密 着しているのかどうかといら疑問が残る，検査の際には 大小 3 種類の耳烃を用意し，被検者の外耳道に合わせて 使用したのであるが，椧查途中ではめ直すと前後覚が変

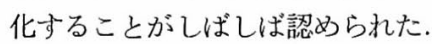

5）聴覚疲労の影響（検査 24 )

耳栓によつて前後覚が影響されるならば，恥覚波労を 起した場合も同様に影響されるのではないかと考兄られ る。 そこで耳栓の場合に似せて $4000 \mathrm{cps}$ 附近で聴覚疲 労を起させて前後覚をしらべた．まづ被検者に正中前後 または正中より $30^{\circ}$ 偏つた方角の前後上り $1 / 2$ オクター ブ巾欠 WN 9 種を順不同で 30 秒につき 12 コの割合で $\mathrm{SL} 30 \mathrm{db}$ の強さで聞かせ，前後の弁別が 100\%良いこ とを確かめた後， $3000 \mathrm{cps} 90 \mathrm{db} 2$ 分間の刺钱音を与克， その刺㦸 終了直後より再び同様にして前後覚をしらべ た. 検査対象に $30 \sim 70$ 才の健康人 27 名（ठ 22 名 95 
名）である。耳柽の場合之暴り聴覚疲觉は回復に㭙日を 要するので同一人につつけて何回む柃在をくり返すこと はできなかた、ところで前記刺战音でどれだけの聴覚 疲労が起るかを自記オージオメーターを用い，その㳖作 に熟練した当教室員 10 名について測定した所图 10 に示 すごとく刺战直後には活ぼ 30〜60db の闘値上舁がみら れるが，殆んどの人から3分以内に 50\%あるいはそれ 以上の回復が みられるので，前後覚も刺㦸後 1 分 30 秒 間 36 音について追求した，得られた結果を表 15 亿示 す.

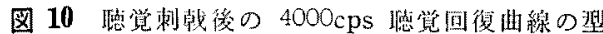
正常人 10 名中A型カーブに近いもの 6 名 B型カーブに近いるの4名

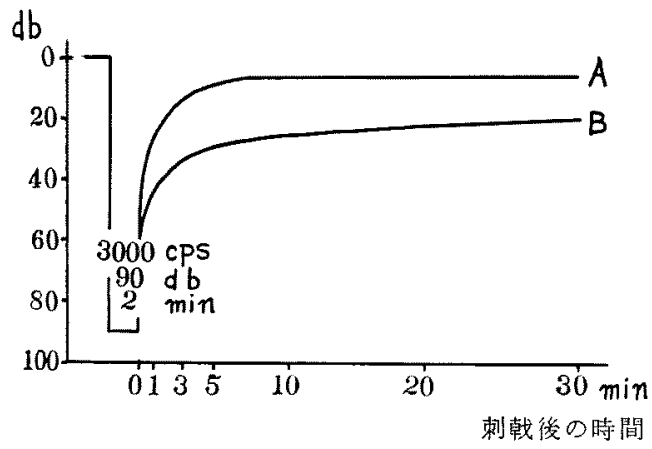

効果の判定は全く前後覚に变化を抢上ぼさない場合を (-) とし，36 音中 1 ケの前後を愦るものを $( \pm) ， 2$ 人

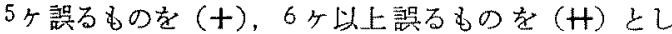
た，結局両耳疲学時は正中前後音に対しても $30^{\circ}-150^{\circ}$ $\left(330^{\circ}\right.$-210 $)$ 音に対しても前後覚はあまり悪化しない が，片耳疲労時は音源に近い方の耳の時は前後覚が著明 飞悪化するが遠い方の耳の時は悪化するものもあり，不 変のものもあつた，な效果で士と十のものは殆んど始 めの 30 秒間においての及前後を誤るものであつた．正

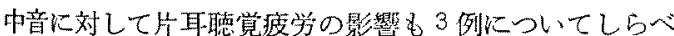
たが前後覚の变化は認められなかつた。

表 15 德觉疲学時の前後党の昰化

\begin{tabular}{|c|c|c|c|c|c|c|}
\hline \multirow{2}{*}{$\begin{array}{l}\text { 音源の } \\
\text { 方 }\end{array}$} & \multirow{2}{*}{ 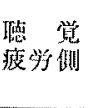 } & \multirow{2}{*}{ 被检老数 } & \multicolumn{4}{|c|}{ 疲学效果の認められる人数 } \\
\hline & & & $H$ & + & \pm & - \\
\hline $0-180^{\circ}$ & 两 倒 & 6 & 0 & 0 & 3 & 3 \\
\hline $150^{\circ}$ & 耐 侧 & 6 & 0 & 2 & 0 & 4 \\
\hline $\begin{array}{c}\text { または } \\
330^{\circ}\end{array}$ & 近耳:侧 & 9 & 5 & 3 & 0 & 1 \\
\hline 210 & 遠耳侧 & 6 & 2 & 0 & 3 & 1 \\
\hline
\end{tabular}

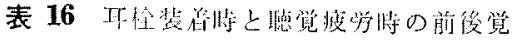

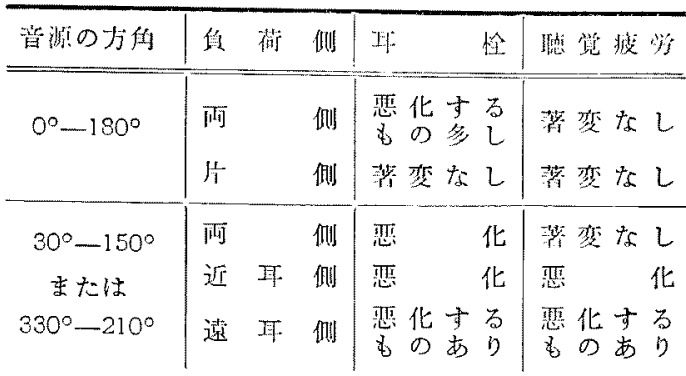

以上耳栓に上る前後覚の变化と聴覚疲労に上るそれを 比較してみると表16のごとくなる。

7) 小 括

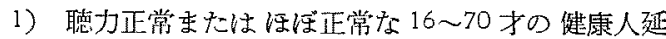
141 名（891名950名）飞ついて，音装聞人人の桑件 をいろいろと変劣た場合の前後覚に及ばす影響をしらべ た。

2）性別汇よる前後覚の相違は認められなかつた。被 㭘者の年令が增加するにつれて前後覚の悪化がみられ た. しかし聴力正常な16５4 才の健康人 30 名中洴後觉 不良な 48 才今の 1 例を除くと残りは皆同程度の前後觉 を示した。

3）被検者が自ら頭を静止させた場合には正中前後上 りの1オクターブウ $\mathrm{BN}$ に対する前後覚は良くないが， 检查音の鳴る之同時汇頭を一方へ水平面内で $5^{\circ}$ まわす と前後覚は格別に良くなり，その効果は嵪い周波数に括 いて著明であつた。

4）被検者の両側頭部にマイクロホンをつけレシーバ 一を通して出力を反対側の耳に入れて音を聞く場合，賈 部静止時では正中前後音の定位は全くできないが，検音 音と同時汇頭を $5^{\circ} ま わ す と$ 前の音は後に，後の音は前 に定位される。

5）被娭者を䉓動椅子にのせて振子様回転させながら 正中前後より音を聞かせた時㤝，静上時に比して良い前

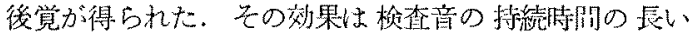
程，またその成分周㳊数が高い程大であつた。

6）頭を被梌者自ら動かさ奴上うにした場命と支柱に

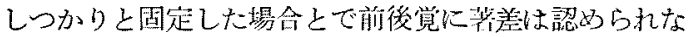
からた.

7）雨耳\&桎装着時の前後觉は留化与る例が多い，片 耳栓の㭙は音源が正中面上り左右へ $30^{\circ}$ 寄つた方角にあ つて，音源に近い力の耳に姶を装碓した場合にのみ前 後覚は落明に悪化する。逗い力の耳の場合は悪化しない 
例が多い。

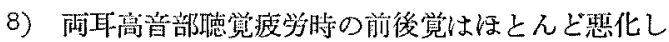
ないが片耳媤覚疲労時は音源が正中面より左右へ $30^{\circ}$ 寄 つた方角にあつて音源に近い方の耳に疲学がある特は前 後覚は著明に悪化した。适い力の耳の場合惡化しない例 が多い.

\section{III 臨床的研究}

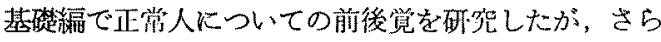
に各種耳疾患や中枢疾患を有する患者に和ける前後覚に ついて研筧した。.

\section{A 隔床的前後觉椧查法}

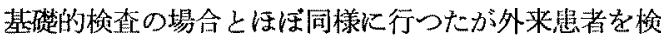
查する場合，何度も来院してもらえないことが多いの で,すぐにの場で手軽に行えることが空ましい，そこで 図11に示すごとく防音聴力检亘室の中央（I） K被檢 者を閐眼で座らせ，その前啳 $1 \mathrm{~m}$ の所で耳の高さに音 源をおき前後覚をしらべ，ついで被検者のみ右へ $45^{\circ}$ 寄 つた位置（『）へ移動させ同じ音を聞かせ，最啳に左へ $45^{\circ}$ 等つた位圆（四）で同様にして前媵覚をしらべた。

（I）（价）の位置の場合音源との距離が、 $2 \mathrm{~m} に な り ，$ からスピーカ一が被桧者の方を向いていないのである が，装置を動かさなくて済さ点至つて簡便で監床的に检 查を行いや寸い。

検查音として子小テープに録音してある次の 2 種類を 用いた。

テープ 1)； $\mathrm{PN}, \mathrm{WN}$ 括よび WNを周波数カット して作つた BN で周波数成分が O 850cps, 850 2400 cps, $2400 \mathrm{cps} \sim 03$ 種計 5 種類各々 8 音づつで前後よ り順不同で酎るようにしてある。

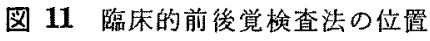
(上からみたところ)

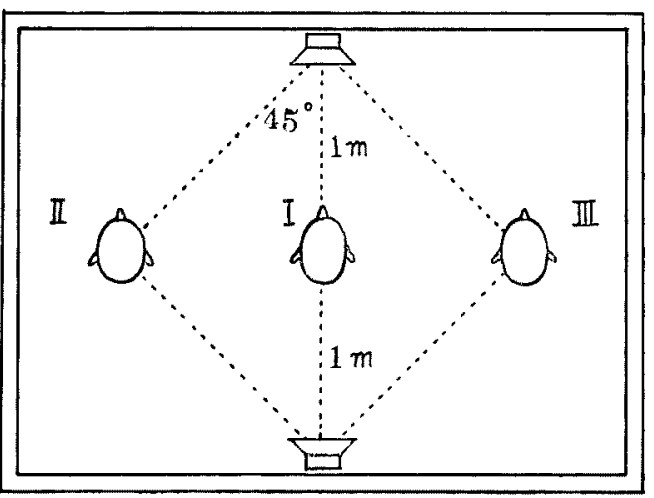

テープ 2)；1/2ホクターブ巾欠 WN 5 種類（検查 11 参䀡) を2音づつ 10 音を一組とし, 強さが SL 20db 〜60db 迄 $10 \mathrm{db}$ 短に強く鳴るように録穴してある.

テープ1は被检者の閶值上 SL 40〜 $50 \mathrm{db}$ の強さで聞

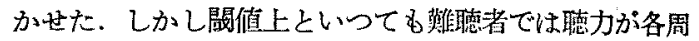
汥数で同程度忢いとは限らないのでどの周没数闌值とす るか問題である。一応 $1000 \mathrm{cps}$ を基準とし高音難聴例 ではやや多い目に音量をあげ思者にとつて充分聞党る強 さで行つた，テープ2) は主として難罚者に用いる目的

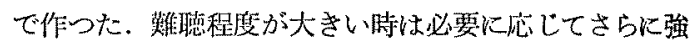
く䳛らした。

$B$ 前後覚の判定について

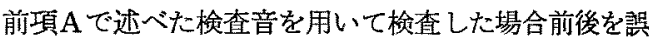
る数と不明の数の何\%をるつて前後覚正常あるいは異常 と定めるかが闍題である，そこで正常人についてこの检 查音での正常範国を定めた。

1) テープ 1 使用の場合 (检查 25 )

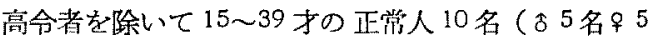

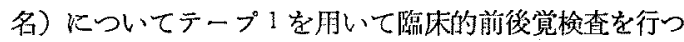
た. 表 17 に前後を器る数と不明の数の巫均 $\mathrm{m}$ 之標準 倨差 $\sigma$ を示す.

表 17 正常人の場命の8 音中の前後を謂る数 と不明の数の平均 $\mathrm{m}$ とその標隻偏差

\begin{tabular}{|c|c|c|c|c|c|c|}
\hline \multirow{2}{*}{\multicolumn{2}{|c|}{$\begin{array}{l}\text { 検查音の種類と } \\
\text { その周波数溗䎳 }\end{array}$}} & \multirow{4}{*}{$\begin{array}{l}\mathrm{PN} \\
1.5 \\
1.56\end{array}$} & \multirow{4}{*}{$\begin{array}{l}\text { WN } \\
0.1 \\
0.30\end{array}$} & \multicolumn{3}{|c|}{ B $\quad \mathrm{N}$} \\
\hline & & & & \multicolumn{3}{|c|}{$\mid$\begin{tabular}{r|rr|r} 
cps & 850 & cps & cps \\
$0 \sim 850$ & $\sim 2400$ & $2400 \sim$
\end{tabular}} \\
\hline \multirow{2}{*}{$0-180^{\circ}$} & $\mathrm{m}$ & & & 2.9 & 2.5 & 0.5 \\
\hline & is & & & 2.04 & 1.63 & 0.67 \\
\hline \multirow{2}{*}{$45^{\circ}-135^{\circ}$} & $\mathrm{m}$ & 0.5 & 0.1 & 2.1 & 0.8 & 0.3 \\
\hline & $\sigma$ & 0.67 & 0.30 & 1.64 & 1.16 & 0.46 \\
\hline \multirow{2}{*}{$315^{\circ}-225^{\circ}$} & 11 & 0.2 & 0 & 1.3 & 0.9 & 0.3 \\
\hline & $\sigma$ & 0.40 & 0 & 1.63 & 1.22 & 0.10 \\
\hline
\end{tabular}

ところで検查音には正常者には殆んど100\%前後がよ く分り難媤者に㤋分りにくい音 (WN 等) があること や，前後の答方方で正答するか愦るかの三通りしかない ことや，さらに德力正沙な健康人の中に前後觉不良の人 が入つていることがあるなどの理由で標潐偏差を重要視 寸ることは適切でない，そこで。 の值を参昭にしつつ 奏際に検查を行つてみて正常䉗囲を表 18 のことくに定 めた. 


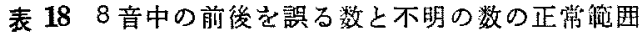

\begin{tabular}{|c|c|c|c|c|c|c|c|}
\hline \multirow{2}{*}{\multicolumn{3}{|c|}{ 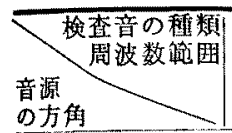 }} & \multirow[b]{2}{*}{$\mathrm{PN}$} & \multirow{2}{*}{ WN } & \multicolumn{3}{|c|}{ B $\quad \mathrm{N}$} \\
\hline & & & & & $\begin{array}{r}\text { cps } \\
0 \sim 850 \\
\end{array}$ & $\begin{array}{rr}350 & \mathrm{cps} \\
\sim 2400\end{array}$ & $\begin{array}{r}\text { cps } \\
2400 \sim\end{array}$ \\
\hline $0^{\circ}$ & - & $180^{\circ}$ & 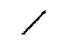 & $\leqq 1$ & $\gamma$ & $Y$ & $\leqq 2$ \\
\hline $\begin{array}{r}45^{\circ} \\
315^{\circ}\end{array}$ & - & $\begin{array}{l}135^{\circ} \\
225^{\circ}\end{array}$ & $\leqq 2$ & $\leqq 1$ & 1 & $\leqq 3$ & $\leqq 1$ \\
\hline
\end{tabular}

BN 0 $850 \mathrm{cps}$ BN $850 \sim 2400 \mathrm{cps}$ は正常人で分りに くい音であるが，疾患例で前後がよく分る例もあるか子 知れないので，正常範囲を定めるのには役に立たないが 検查音としては残した。李た既述のごとく音色の記憶を 防ぐよいう意味での存在洒值もある。

ところで実際上 WN や BN 2400〜 K対する前後賞 のわるい人は PN でも BN 850 2400cps でも䍐いの で，繁樵さを避けるために WN と BN 2400〜のみを 判定に用い正常籍围を越えるもの学前後覚異常とした。

2) テープ 2 使用時の前後覚の正常範囲（検查 26）

高令者を险いた 19〜38才の正常人10名（\$4名早6 名）について臨床的前後賞惍查を行つた。

各 $\mathrm{db}$ の強さに淤ける 10 音中の前後を誤る数と不明 の数の平均を表 19 に示す.

表 19 正常人の1/2オクターブや久 WN 10音中の前後を誤る数と不明の数の平均

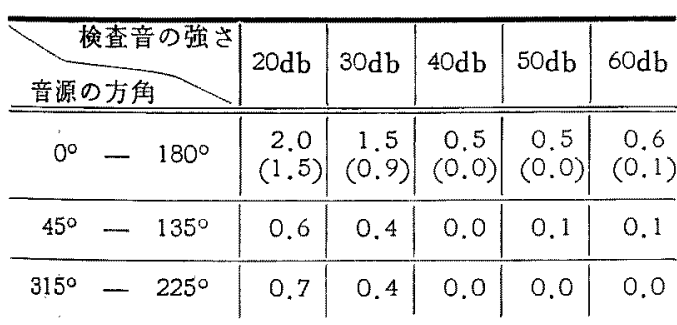

38 才。の1人が正中音に対してのみ前後を全く区別 できないので正中での成瀻が少し瑟いが，この1人を除 くと表19（）で示すよらになり左右側の場合と其に いつれも前後を䛣る数之不明の数は極あて少い，とこで テープ2を聞かせた場合検查音量を增すにつれて前後を 100\%定位できる时は前後觉正常とし，梌查音が弦くな るにつれて悪い前後賞が政善されて行くものを仮性前後 党異常，検查音量に関係なく前後の定位が腎いbのを真 性前後覚異常と名付けることにする。
C 各㮔疾患と前後覚

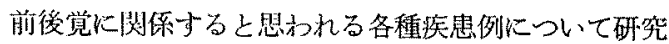

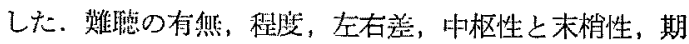

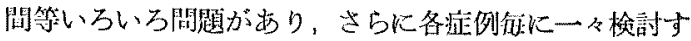

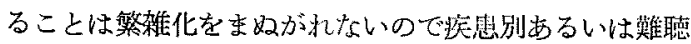
の程度の似た例のみ集めて前後觉を梌盗した。

1) 神紹性耳鳴

検查対象は 15 44才の7名（84名早3名）で耳鳴は 雨側にあつてキーンとかザー，ジー等いろいろである。 聴力間值俩両側共正常である、テープ1を聞かせた時の 前後を誤る数と不明の数の\%は表 20 に，前後覚の判定 は表 21 に示与. 比較的正常人に近い前後覚を示す.

2) 神緯性䧼㯖

i) 両唰中等 高度難聴

両故膜正常で両気骨導聴力損失が中等〜高度でかっ左 右で等しい19〜67 ボの10名（36名早4名）を選んた。. その気緮聴力の平㚬を図 12 に示す。
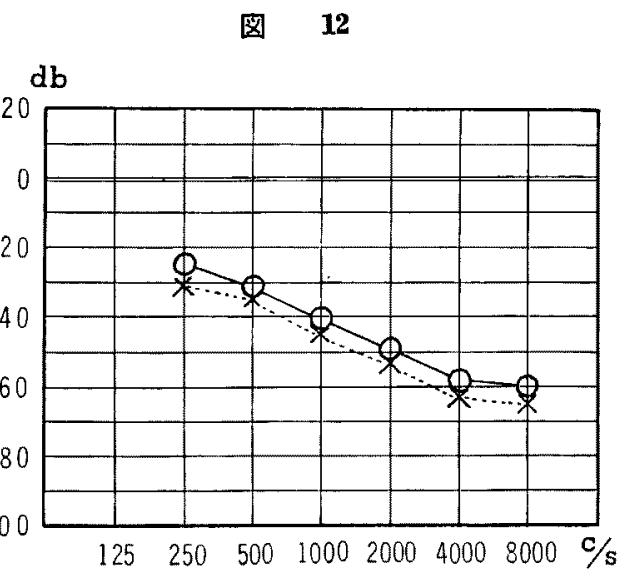

テープ1を聞かせた跀の前後を㟪る数と不明の数の\% は表 20 に，前後覚の判定は表 21 に示す．3万向共前後 党のわるい8例はいずれも比較的高令者であつた，

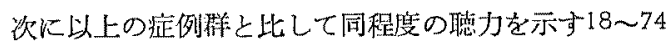
才の8名(84名字4名) についてテープ2を聞かせた 所，2名は3万向共仮性前後觉異常，1名は $0^{\circ}-180^{\circ}$ 万 向の灭仮性異常で他の 2 万向は真性暴常を゙示し，のこり 5 名は 3 万问共点幽前後覚異常を示した。

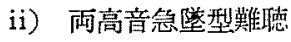

致膛正常で $4000 \mathrm{cps}$ 以上の周波数で网気骨 導聴力損

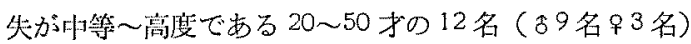
についてテープ1を聞かせた時の前後を䛿る数と不明の 


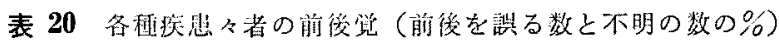

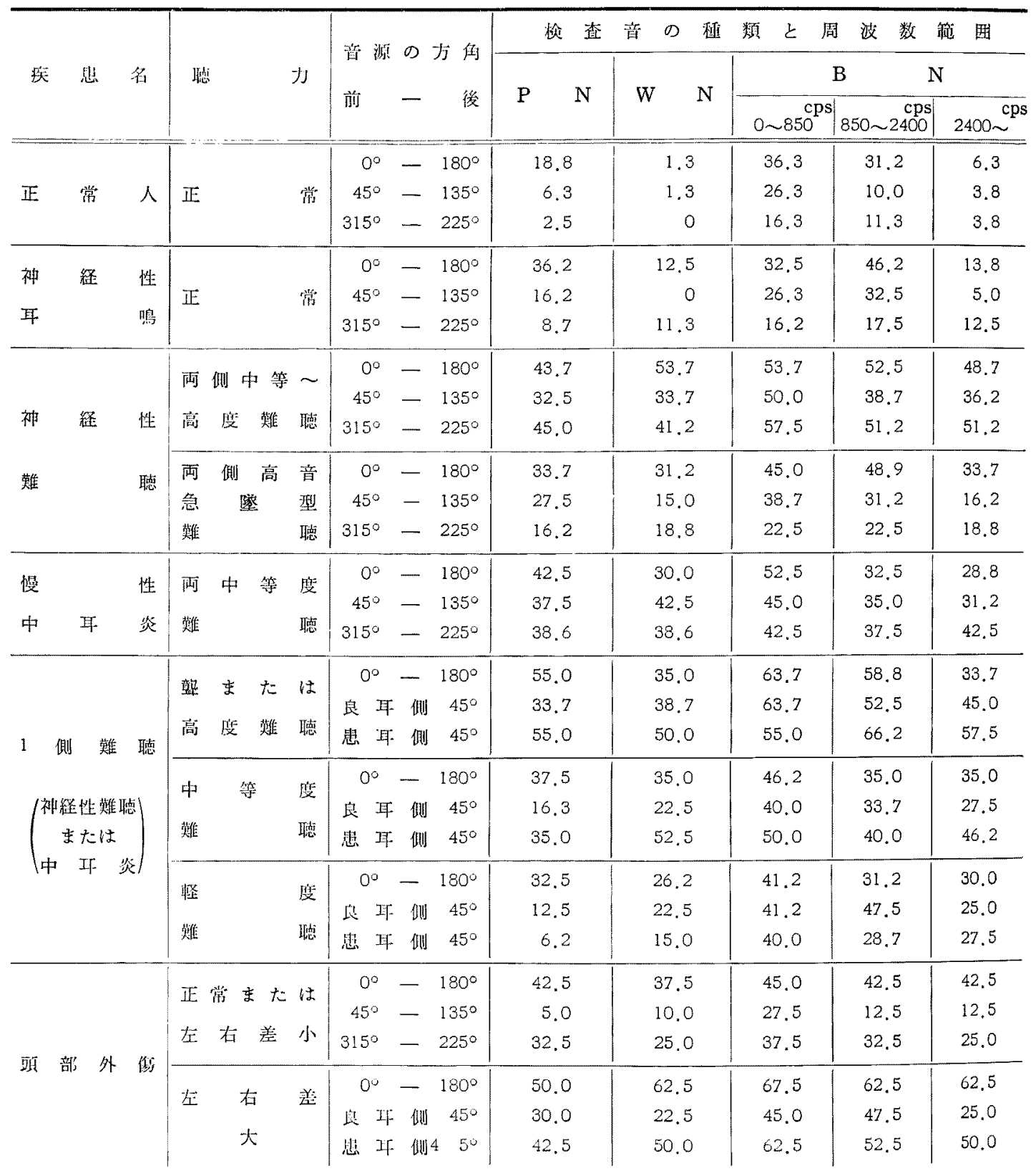


表 21 各種笑患及者の前後覚異常者数

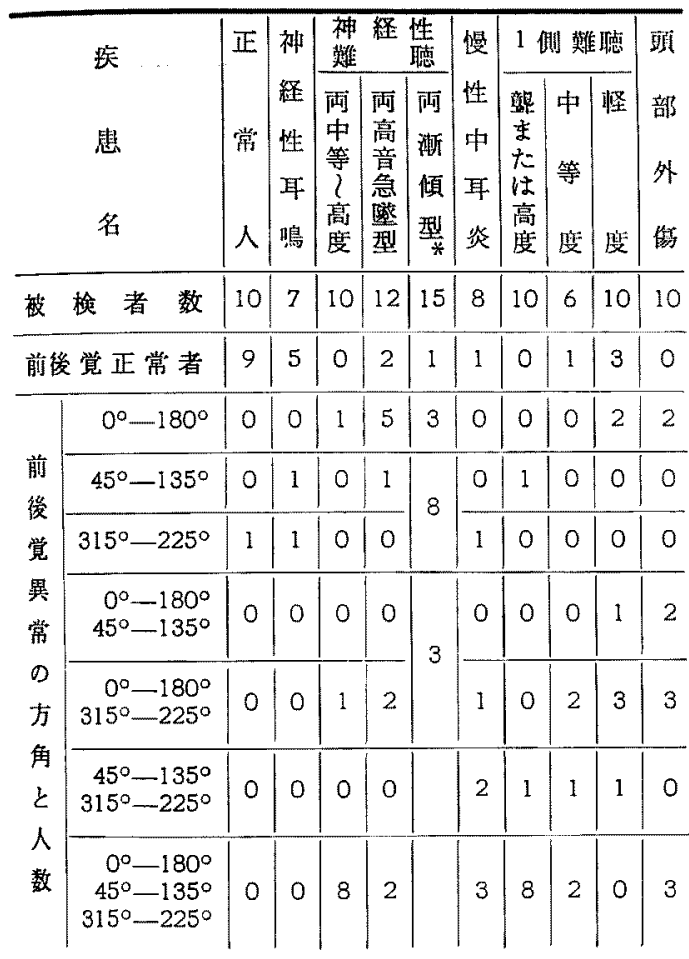

* 漸傾型のみ検查法やや異る（本文参照）

\section{図 13}

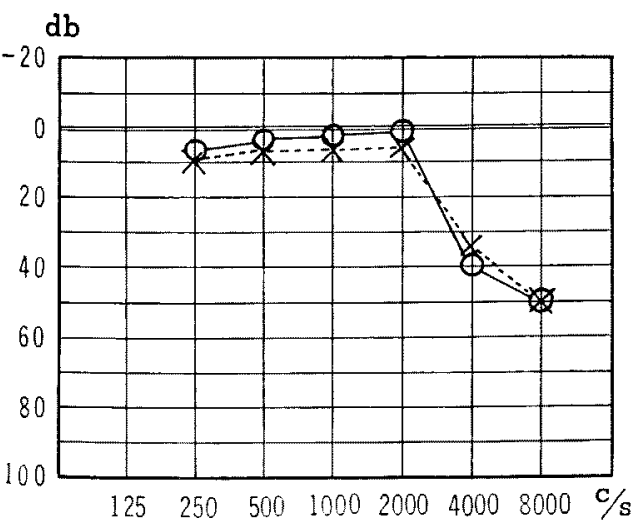

数の\%は表 20 に，前後覚の 判定は表 21 に示す. 図 13 はこれら12名の気導聴力の平均である。

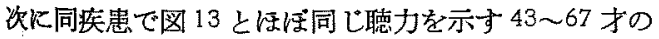
8名（87名91名）についてテープ2を聞かせた所8名 中3方向共正常前後覚を示す为のは1例のみだ，正中方 向のみ真性前後覚異常のもの 1 例, 正中方向と 1 側が真

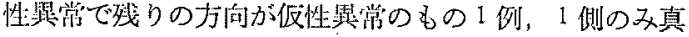
性異常のもの2 例， 3 方向共真性蹎常のもの3 例であつ た. 先の綪果と含わせて考方ると $4000 \mathrm{cps}$ 以上が聞え

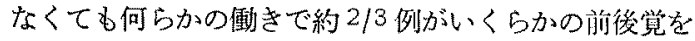
有するるのと思われる。

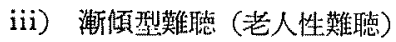

本項に限り被榆者は大阪底立成人病センター人間ドッ クに入院中の患者76名（359名中17名）で检查の力洗 は今迄通りであるが，当教室防音德力检查室より小さい 同センターの聴力检査室で行つたため $0^{\circ}-180^{\circ}$ 音ば正 中前後 $1 \mathrm{~m}$ の距離に音源を括く点では同じであるが，

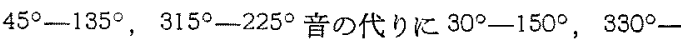
$210^{\circ}$ 音を用いた，かつ部屋の楎造上全く左右刘称の位 固で検查を行うことが不可能で多つたので $30^{\circ}-150^{\circ}$ 音

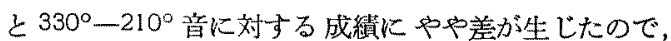
今回に限りこの2方向安一括してその平约値を用いるこ とにした，正常範冊が問題であるが，一広今迄と同じ基 準を用いて差支えないかどうかについて愉查を行つた中 の聴力正常者を選んで榆馀した。

1）聴力正常者の場合

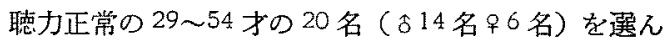
でテープ1を聞かれた時の前後を嵒る数と不明の数の\% は表 22 のごとくで表 17 と此較して殆んど差認められ ない，前後觉を判定可れば表 23 のごとく多少異常者が みられるが，被検者全員が聴力正常とはいえ人間ドック 入院中の中年〜高令者とい5条件を考慮以入れれば本教 室防音聴力検查室で行つた場合と比較して大差なしとい える、よつて正常範缃の基準を变更することなく以下老 人性難悖の前後覚について述べる。

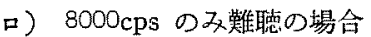

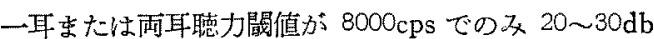
上昇している 42 52 才の8 名 (\$5名果3名)について テープ1を聞かせた時の前後を誛る数と不明の数の\%は 表 22 に前後覚の判定は表 23 に示すごとくで正常聴力者 とあまり違わない，洼洼同じ聴力を示す別の症例 5 名 (33名車2名) についてテープ2聞かせた所 30 才代 の2名は正常前後喾を示し 50 才代 1 名之 60 才代 2 名は 前後覚異常を示した．以上より $8000 \mathrm{cps}$ のみ聴下低下 例ではさしろ老化による中怄性原因により前後覚が瑟化 するすのと思われる。

） $4000 \mathrm{cps}$ と $8000 \mathrm{cps}$ のみ難愊の場合

$4000 \mathrm{cps}$ と $8000 \mathrm{cps}$ に执いて一耳をた注両耳に20

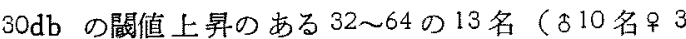


表 22 老人性難聴者の前後を阆る数と 不明の数の\%

\begin{tabular}{|c|c|c|c|c|c|c|}
\hline \multirow{3}{*}{ 聴 力 } & \multirow{3}{*}{ 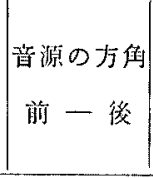 } & \multicolumn{5}{|c|}{ 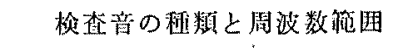 } \\
\hline & & \multirow{2}{*}{ PN } & \multirow{2}{*}{ WN } & \multicolumn{2}{|c|}{ B } & $\mathrm{N}$ \\
\hline & & & & $\begin{array}{r}\text { cps } \\
0 \sim 850\end{array}$ & $\begin{array}{l}850 \mathrm{cps} \\
\sim 2400 \\
\end{array}$ & $\begin{array}{r}\mathrm{cps} \\
2400 \sim\end{array}$ \\
\hline \multirow[b]{2}{*}{ 正 常 } & $0^{\circ}-180^{\circ}$ & 7.5 & 2.5 & 36.3 & 22.5 & 2.5 \\
\hline & $\mid \begin{array}{r}30^{\circ}-150^{\circ} \\
330^{\circ}-210^{\circ}\end{array}$ & 5.0 & 3.8 & 26.3 & 18.8 & 2.5 \\
\hline \multirow{2}{*}{$\begin{array}{c}8000 \mathrm{cps} \\
\text { のみ }\end{array}$} & $0^{\circ}-180^{\circ}$ & 12.5 & 7.5 & 31.2 & 25.0 & 7.5 \\
\hline & $\left|\begin{array}{r}30^{\circ}-150^{\circ} \\
330^{\circ}-210^{\circ}\end{array}\right|$ & 2.5 & 3.8 & 21.2 & 20.0 & 3.8 \\
\hline \multirow{2}{*}{$4000 \mathrm{cps}$} & $0^{\circ}-180^{\circ}$ & 16.3 & 6.3 & 51.2 & 38.7 & 12.5 \\
\hline & $\mid \begin{array}{r}30^{\circ}-150^{\circ} \\
330^{\circ}-210^{\circ}\end{array}$ & 13.8 & 8.8 & 33.8 & 28.8 & 11.3 \\
\hline 漸傾型 & $0^{\circ}-180^{\circ}$ & 35.0 & 15.0 & 28.8 & 40.0 & 27.5 \\
\hline 難 衈 & $\mid \begin{array}{r}30^{\circ}-150^{\circ} \\
330^{\circ}-210^{\circ}\end{array}$ & 32.5 & 20.0 & 42.5 & 45.0 & 22.5 \\
\hline
\end{tabular}

表 23 老人性難㯖者の前後覚買常者数

\begin{tabular}{|c|c|c|c|c|c|}
\hline 槙 & 力 & 正 常 & $\begin{array}{c}8000 \mathrm{cps} \\
\text { ○ }\end{array}$ & $\begin{array}{l}4000 \\
8000^{\mathrm{cps}} \\
\text { のみ難㥁}\end{array}$ & $\begin{array}{l}\text { 渐傾型 } \\
\text { 難 聴 }\end{array}$ \\
\hline 被 & 検 者 数 & 20 & 8 & 13 & 15 \\
\hline \multicolumn{2}{|c|}{ 前後覚正常者 } & 17 & 6 & 7 & 1 \\
\hline \multirow{3}{*}{$\begin{array}{l}\text { 前 } \\
\text { 後 } \\
\text { 繒 } \\
\text { 蕒 } \\
\text { 常 } \\
\text { 者 }\end{array}$} & $0^{\circ}-180^{\circ}$ & 1 & 1 & 1 & 3 \\
\hline & $\begin{array}{r}30^{\circ}-150^{\circ} \\
330^{\circ}-210^{\circ}\end{array}$ & 2 & 1 & 4 & 8 \\
\hline & $\begin{array}{r}0^{\circ}-180^{\circ} \\
30^{\circ}-150^{\circ} \\
330^{\circ}-210^{\circ}\end{array}$ & 0 & 0 & 1 & 3 \\
\hline
\end{tabular}

名）についてテープ1を聞か女た時の前後を誤る数と不 明の数の\%は表 22 に, 前後覚の判定は表 23 に示与。

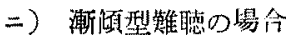

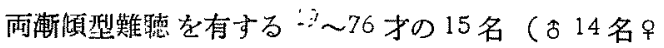
1名)についてテープ1を聞かせた時の前後を言る数と 不明の数の\%は裴 22 ，前後覚の判定は䘚 23 に示すご とくで殆えどが不良である，図14 はこれら15 例の気賉 聴力の平䝆である。

次に図 14 とほ活同じ聴力像を示寸52 70 才の 15 名
图 14

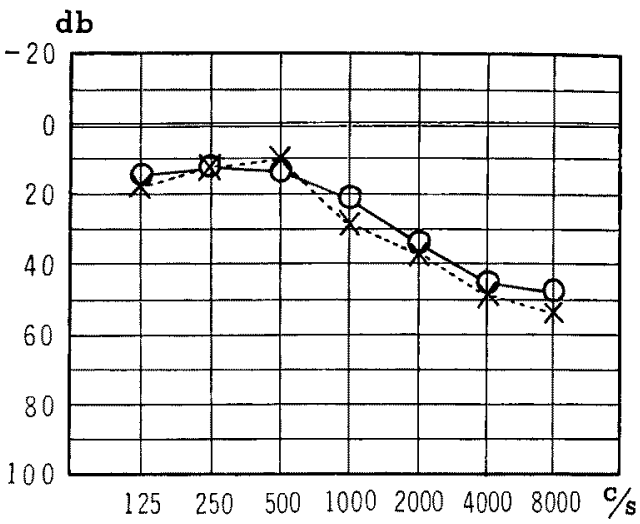

(313名里 2 名)についてテープ2を聞かせた所。3方 向共正常前後覚を示するのは1例路ず，3方向共真 性前後覚異常のもの3 例, その他訬くとも1方向に巽 常が認められた。

ただ面白いことに愉查音の音量を增大するにつれて一 旦良くなつた前後覚が再び覀化する例が 5 例にみられた がここれは正常人では絶対みられなかつた現象である。

\section{3) 慢性中耳炎}

両僈性 中耳炎を有し気導聴力が 各夙波数で左右等し

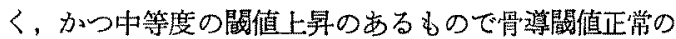
16〜44才の8 名 (12 名96名) についてテープ1を聞 かせた場合の前後を愦る数と不明の数の\%は表 20 K， 前後覚の判定は表 21 に示す.

図15はこれらの気道衈力の平均である。

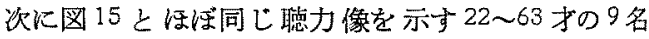
(35名94名)についてテープ2を聞か度た所正常前後

図 15

\section{$\mathrm{db}$}

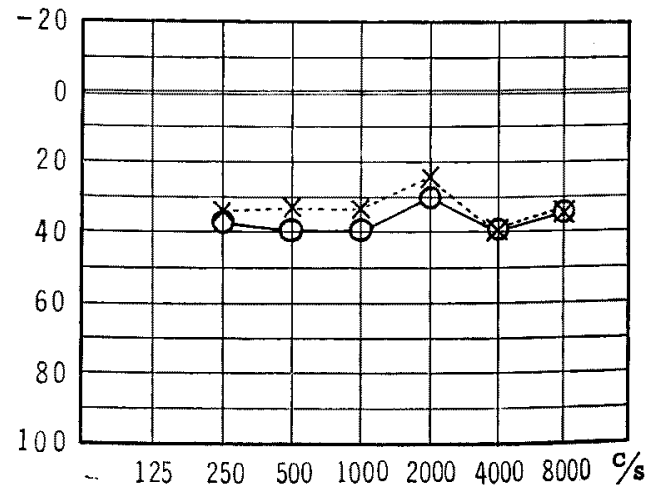




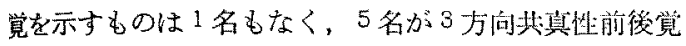
異常を示し，のこりの4名も其性前後觉異常に近いが1 方向または 2 方向に和いて检查音が強くなるにつれて前

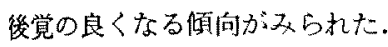

3') 慢性上耳耳炎術倦

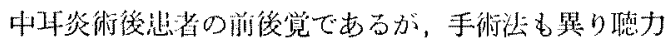
もいるいろであるので一括してまとめることは困難で 個々の症例について还べる。

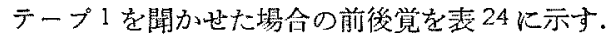

表 24 慢性中耳炎街後㭧者の前後営

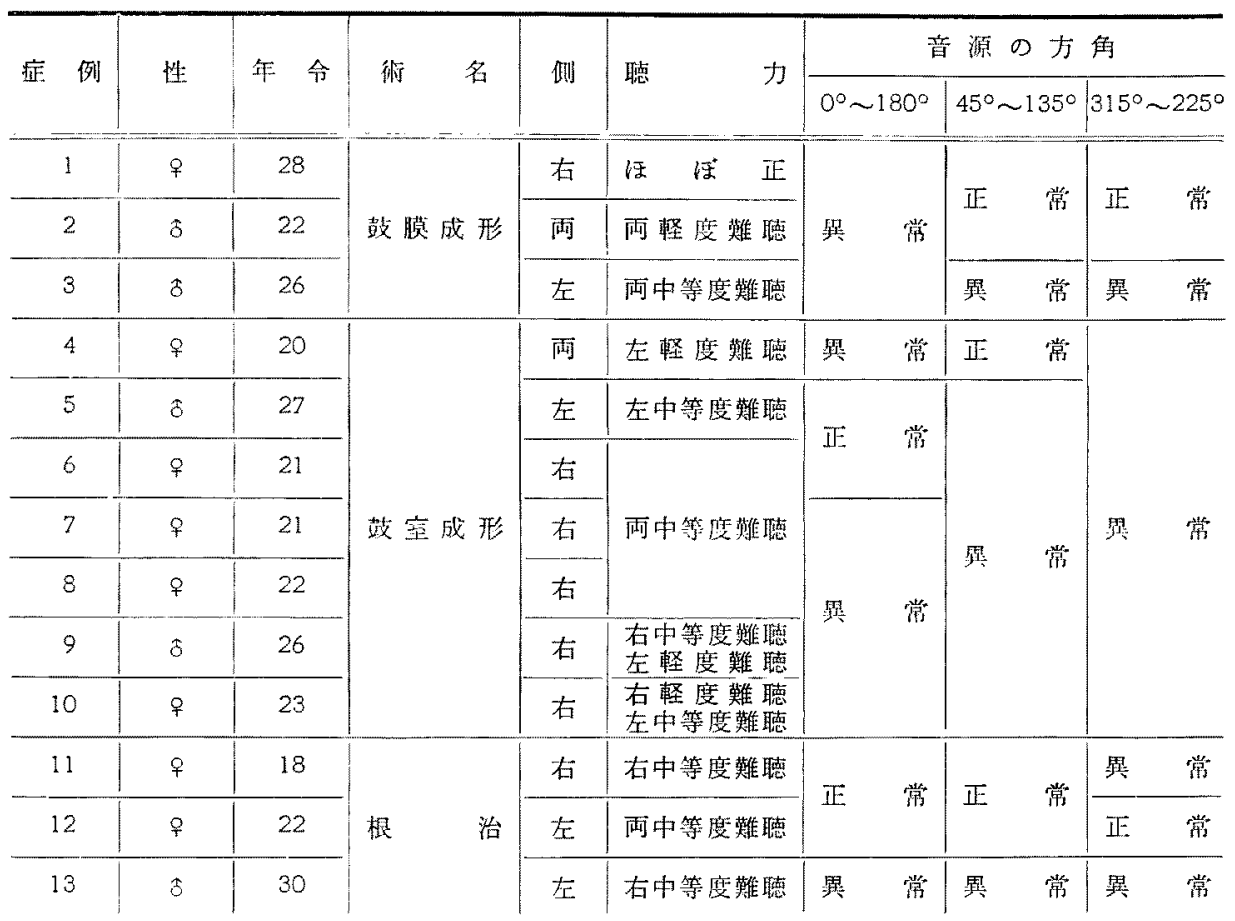

\section{4) 1 側 難 聴}

l側耳にの文難聴を有する場合，音源の方角に上る差 は健耳側と患耳側で異ると考光られるので，正中面より

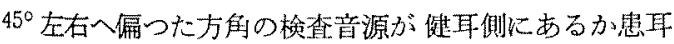
㫠にあるかによつてその成績をむとめたたと之ば右雭 耳の人で $45^{\circ}-135^{\circ}$ 音の場合と左患耳の人て $315^{\circ}-225^{\circ}$ 音の場合とを同等に取报うわけである。

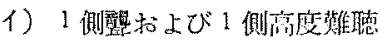

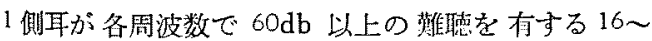
51 才の10名(87名93名)についてテープ1を聞か せた時の前後を䛠る数と不明の数の\%は表 20 に, 前後 覚は表21に示すように極めてわるい，音源位琵わ゚良耳

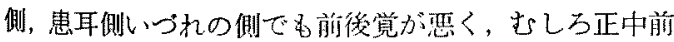
後音の時の方か゚よい点正常人とは異つている。

\section{口) 1 側中等度難㯖}

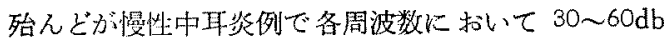

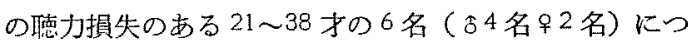
いてテープIを聞かせた持の前後を器る数之不明の数の \%は表 20 に, 前後覚の判定は表 21 に示すように一般に

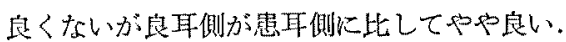

\section{八) 1 側軽度難悖}

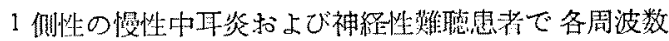
で 10〜30db の㯖力損失を有する19〜32才の10名（な 6 名果 4 名) についてテープ1を聞かせた時の前後を誤 万数と不明の数の\%は表 20 に，前後営の判定は表 21 に 示与 前後党は比校的よい，また良耳側 $45^{\circ}$ 音の場合に 良い前後筧を示寸とは限らなかいた。図16はこれら10 名の気算埴力の平均を示寸 


\section{图 $\quad 16$}

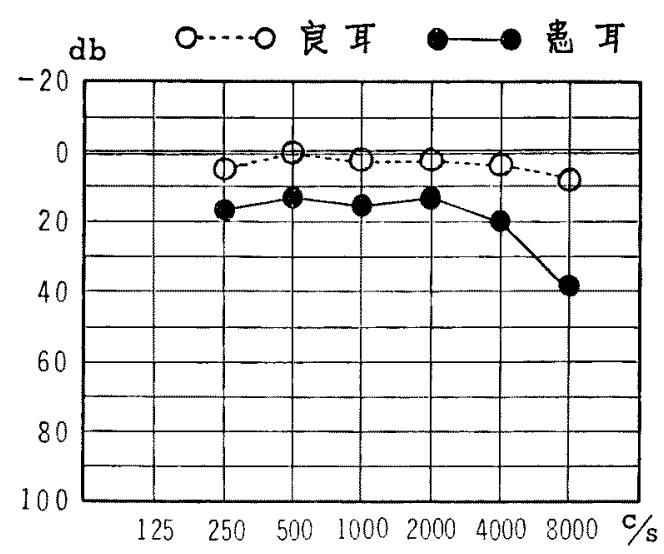

$\Rightarrow 1$ 側難德と検查音の強さとの関係

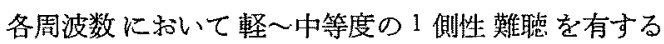
14 68才の患者（主として慢性中耳炎）10名（87名

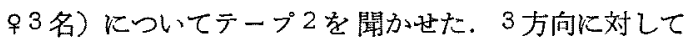

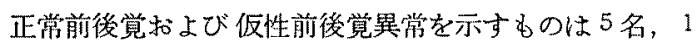
乃至3方向音に対して真性前倦覚異常を示する05名で あつた。

以上一側難聴の程度と前後覚不良の程度とは必ずしも 一致しない場合もあり，また良耳側 $45^{\circ}$ 音に対する前後 筧が良いと为限らなからた。

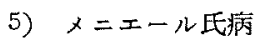

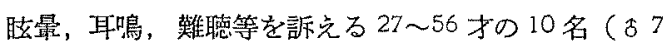
名年名)についてテープ1を聞か好た３方向共正常 前後覚を示寸6の 2 名, 正中音に対しての及前後覚異常 のもの3名でこれらはいづれも難聴の少い, 左右差の少 いものであつた：他の一側に中等度難㯖を有する5例な 1〜3方向音に対して前後覚異常を示した.

次に別の聴力正常またははぼ正常の $27 \sim 43$ 才の 5 名

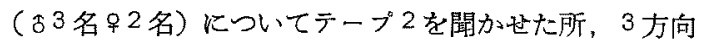
共正常前後党の\&の1例，正中音の及仮性異常のもの1 例, 正中括よび $315^{\circ}-225^{\circ}$ 音のみ真性異常のもの1 例 で3方向共真性前後覚罣常のものが1例みられた。

6) 中枢疾患

i) 頭部外傷

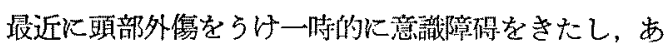
るいは難聴耳鳴をのこした 18〜64才の10名（38名早

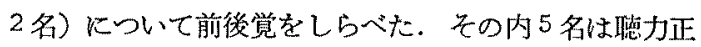
常または難聴の程度が軽く平均聴力は $250 \sim 4000 \mathrm{cps}$ で 左右共 $10 \mathrm{db}$ 以内, $8000 \mathrm{cps}$ の及 $20 \sim 30 \mathrm{db}$ の損失方
ある.のこりの5名は左右差が大で衈力低下の程度も著

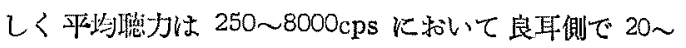
$35 \mathrm{db}$, 㭧耳側で 50 60db の聴力低下がある.これらの 2 群についてテーブ1を聞かせた時の前後を誤る数と不 明の数の\%は㤗 20 に, 前後觉の判定は婊 21 に示す通り で㷙後覚正常渚山1名もみられなかつた。

ii) 脸腯湯

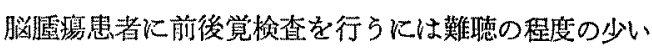
両耳差の少いものでなけわば，得られた成績が難聴に基 づく外来信号の欠如による前後筧不良なのか，矢れとる 中枢に持ける前後判断が莤いのか区別し難い，また患者 は歩けて㯖力検查室にくることができ，発語障碍などな くて前後をすぐ答えられなければならない.こらいつた 症例はそ万簡単に沢山得られないので長期にわたり集め たが，この間前後覚検查法わいるいる改良を加えている ので全例必ずしも同一検查法を行つていないので個々の 症例について検查法を併記してその榆查法の正常人にお ける場合と比較してみた。

第1例 溝○睛○ 44 才。

2〜3年来頭痛時に悪心嘔吐，手足のしびれ感あり， $l$-carotis $\infty$ angiography $に \tau$ frontparietal portion の異常がみられる. 聴力は左右差なく 250〜2000 cps は $20 \mathrm{db}$ 以内， $4000 \sim 8000 \mathrm{cps}$ は $25 \mathrm{db}$ の聴力損失があ る. 1/2オクターブ巾欠 WN を SL 30dbで聞かせた 所 $0^{\circ}-180^{\circ}$ 和よび $45^{\circ}-135^{\circ}$ 音に対して 全く前後覚不 良ですべての音は前から聞える。 $315^{\circ}-225^{\circ}$ 音に対し ては前後を誤る数と不明の数の\%は20\%であつた。 TTS 検查では (一) である.

第 2 例 井○純○ 51 才

2 留前突然右下肢の運動障碍あり，現在起立困難，

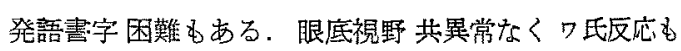
$(-)$, PEG $K \tau$ l-cerebulopontine angle tumor 疑われる。德力は $8000 \mathrm{cps}$ を除左右差なく 15 35db の漸㑯型を示しているが $8000 \mathrm{cps}$ で右 $0 \mathrm{db}$, 左 $50 \mathrm{db}$ の闘值上昇がある１/2オタターブ币久 WNを SL $30 \mathrm{db} て ゙$ 聞加した所 $0^{\circ}-180^{\circ}$ 至に対して前後覚良好で

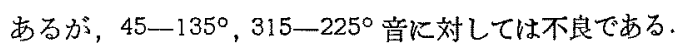
检查音をつよくするとろ方向共良くなつた。

第3例上○美○ $37 才 \%$

$l$-fronttemporal portion $\odot$ meningioma 術後例で 悶力は全く正常である. 術後 3 週間日の㭙は1/2オクタ 一ブ巾欠 WN SL 30db に対し前後覚は全く不良で音 は全部前から聞えた，SL 60dbにすると手别がでさる 


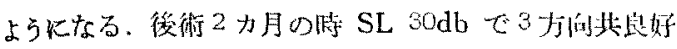
な前後覚を示した。

第 4 例 中OとOO 54 才 \%

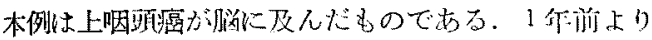

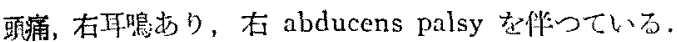
$\checkmark$ 線比 $\tau$ os sphenoides, processus clinoideus post. の破壞, sella の拉大, r-int. carotid artery の狭窄方

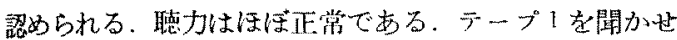
た所 3 方向共前後觉買常を示した。

\section{第 5 例 140 芳 36 才 5}

複視を挀光 partial oculomot. palsy 有し parasellar tumor 功疑われる. 缌力は左 8000 cps で $20 \mathrm{db}$, 右 $4000 \mathrm{cps}$ で $25 \mathrm{db}$ の闘值上算がある。テープ1で正 中前後音に対して正常前後覚る示したが左右 $45^{\circ}$ 管に対 して罢常を示した。

\section{第6例 大○幸○郎 62 才。}

脑下垂体廆瘍例で, hemianopsia bitemporalis と雨 atrophia nervi optici simplex がある、レ線にて sella

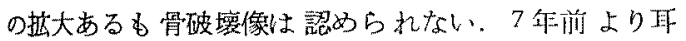
鳴、難㯖あり泍傾型難聴像を示す。

テープ2を聞かせた所 $0^{\circ}-180^{\circ} ， 45^{\circ}-135^{\circ}$ 音に対し 前後覚不良．しかし検查音量の增大と共汇多少良くなる

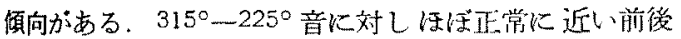

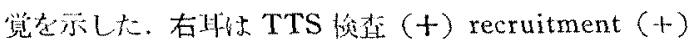
である。

符 7 例 $\mathrm{mO}$ 勇○ 21 才。

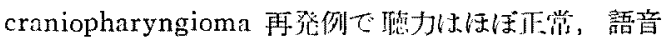

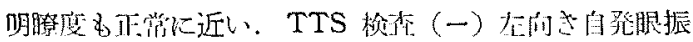

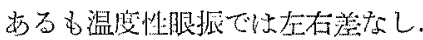

テープ2で3方向共正常湔後覚を示した.

第8例 11例 24 才る 40 才。 52 才㕛 35 才。

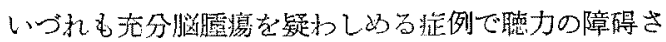

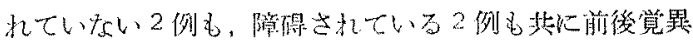
常を示した。

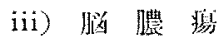

怔例 南○偻 23 才 6

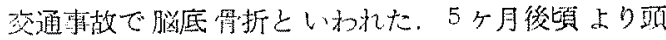
痛, hemianopsia を訴点る。 r-fronttemporal portion

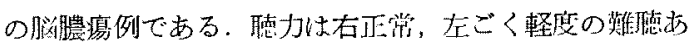

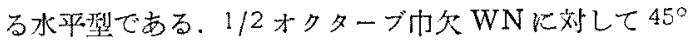

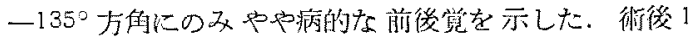

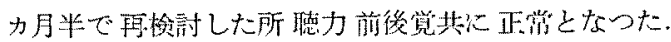

TTS $(-)$ recruitment $(-)$ である。

iv）脳卒中後拈上び高血王症

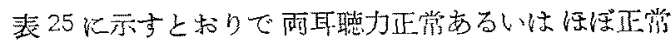
者ですら前後觉異常者が多い。

表 25 脳卒中扰よび高血圧者の前後覚

\begin{tabular}{|c|c|c|c|c|c|c|c|c|c|}
\hline 症例 & 年令 & 性 & 疾患 & $\begin{array}{l}\text { 病歴括よび } \\
\text { 将 }\end{array}$ & $\begin{array}{l}\text { 初剑时 } \\
\text { 血 正 }\end{array}$ & 䛓 & $\begin{array}{l}\text { 前後筧 } \\
\text { 搔查音 }\end{array}$ & is & 令の他 \\
\hline 1 & 40 & $\delta$ & $\begin{array}{l}\text { 脳出血 } \\
\text { 高血正 }\end{array}$ & 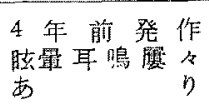 & $\begin{array}{l}140 \\
? \\
90\end{array}$ & 正 & $\begin{array}{c}\text { テープ } \\
1\end{array}$ & 常" & \\
\hline 2 & 46 & $\delta$ & $\begin{array}{l}\text { 畄出血 } \\
\text { 高血生 }\end{array}$ & 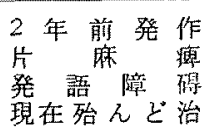 & $\begin{array}{l}130 \\
? \\
90\end{array}$ & $\begin{array}{l}\text { 画側 } 8000 \mathrm{cps} \\
\text { の及 } 30 \mathrm{db} \text { 低下 }\end{array}$ & $\bar{\tau}_{2}$ & 常 & \\
\hline 3 & 62 & $\delta$ & $\begin{array}{l}\text { 脳出血 } \\
\text { 高血正 }\end{array}$ & 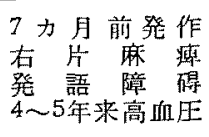 & $\begin{array}{c}210 \\
? \\
100\end{array}$ & 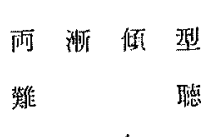 & テープ & 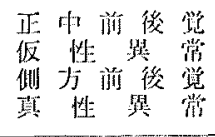 & $\begin{array}{l}\text { 浯点明膫 } \\
\text { 度 } 80 \mathrm{db} \\
\text { で90\% }\end{array}$ \\
\hline 4 & 61 & $\delta$ & 㨫血栓 & $\begin{array}{l}1 \text { 力月前発作 } \\
\text { 発語 做 碍 }\end{array}$ & 正 常 & 活 潘 正常 & $\begin{array}{l}1 / 2 \text { 才 } \\
\text { クター } \\
\text { ブ巾欠 } \\
\text { WN }\end{array}$ & 常 & $\begin{array}{l}\text { 存向き } \\
\text { 自発眼振 }\end{array}$ \\
\hline 5 & 17 & $\delta$ & 脱栓罡 & $\begin{array}{l}\text { 20日前儿発作 } \\
\text { 伝導性失語痽 }\end{array}$ & 正 箈 & $\pi$ & " & $\begin{array}{l}\text { 大側前後覚の欢 } \\
\text { 正: }\end{array}$ & \\
\hline 6 & 56 & \% & 高血正 & 耐 耳 & $\stackrel{184}{\sim 98}$ & $\begin{array}{l}\text { 左 } 8000 \mathrm{cps} \text { の } \\
\text { 石轻度 難 悖 }\end{array}$ & $\begin{array}{c}\text { テープ } \\
1\end{array}$ & 異 & \\
\hline
\end{tabular}




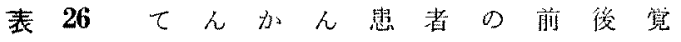

\begin{tabular}{|c|c|c|c|c|c|c|c|c|}
\hline 症 例 & 年 令 & 性 & 病菲 & 状 & 朢 & $\begin{array}{l}\text { 前後 喾 } \\
\text { 检 造 }\end{array}$ & 前 渗 覚 & その他 \\
\hline 1 & 21 & $\hat{\delta}$ & $\begin{array}{l}3 \text { 力 月 } \text { 前 } \\
\text { 奖通青故 }\end{array}$ & 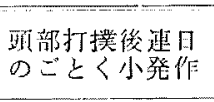 & E 党 & $\begin{array}{l}1 / 2 \text { 才ク } \\
-7 门 久 \\
\text { WN }\end{array}$ & 買 党 & \\
\hline 2 & 36 & $\delta$ & 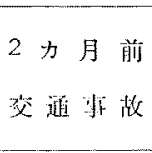 & 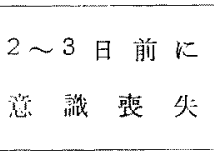 & 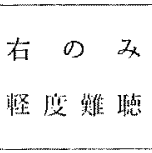 & " & 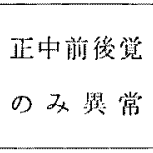 & 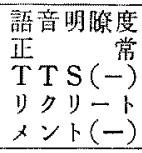 \\
\hline 3 & 8 & 우 & 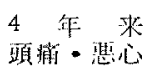 & $\begin{array}{l}\mathrm{EE} \mathrm{E} \mathrm{Gでてんか} \\
\text { んのパーン }\end{array}$ & 正 & $\bar{\tau}-\boldsymbol{\gamma}^{0} 2$ & 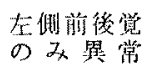 & $\begin{array}{l}\text { 語音明糡度 } \\
\text { 正常 }\end{array}$ \\
\hline 4 & 11 & $\delta$ & $\begin{array}{lll}\text { 月 } & 1 \text { 回 } \\
\text { 小癷 作 }\end{array}$ & & " & $"$ & " & 前庭揄查 \\
\hline
\end{tabular}

v) てんかル

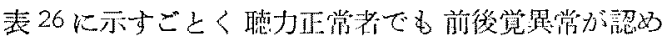

$5+2$ 万

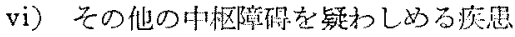

踒 27 に示与ごとき前啳筧でする。

7) 外开疾雭

i) 外耳道閏鎖兼小耳应

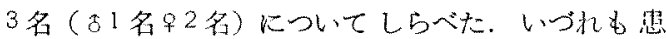

側に高底猫聴を有するためるあつて前後覚は不良であつ た.1例のみ $0^{\circ}$ - $180^{\circ}$ 音に刘して良好な前後覚を示した，

ii) 耳櫭

思耳側で $8000 \mathrm{cps}$ のみ 20〜40db の閴值上昇のある

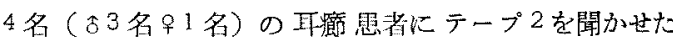

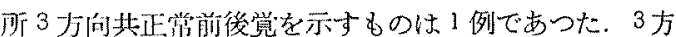

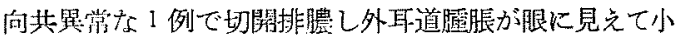
さくなつた所で雨榆した所，高音闘值低下と其に正常前

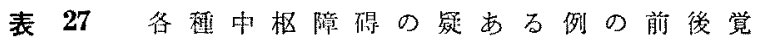

\begin{tabular}{|c|c|c|c|c|c|c|c|c|}
\hline 症 例 & 年 令 & 性 & 疾患 & 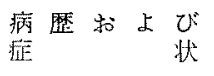 & 力 & $\begin{array}{l}\text { 前 後 覚 } \\
\text { 㯿 查 }\end{array}$ & 前倦 & その他 \\
\hline 1 & 43 & q & 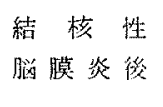 & 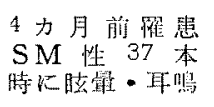 & 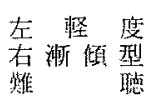 & $\bar{\gamma}-フ^{0} 1$ & 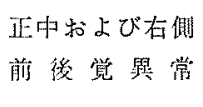 & \\
\hline 2 & 20 & $q$ & 脳腫瑒の晱 & $\begin{array}{l}\text { sensory } \\
\text { aphasia? }\end{array}$ & 整塺難聴 & $\bar{\tau}-\gamma^{\circ} 2$ & $\begin{array}{l}\text { 正中前㣪賞のみ } \\
\text { 正常 }\end{array}$ & $\begin{array}{l}\text { 語晏明滕 } \\
\text { 度 不良 }\end{array}$ \\
\hline 3 & 38 & $q$ & $\begin{array}{l}\text { Cushing } \\
\text { 症 候 棐 }\end{array}$ & & 正 & $\begin{array}{c}1 / 2 \text { オクタ } \\
-7 ゙ \pitchfork \times \\
\text { WN }\end{array}$ & 正 & $\begin{array}{l}\text { 語音明源 } \\
\text { 度 正常 }\end{array}$ \\
\hline 4 & 25 & 3 & 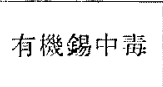 & 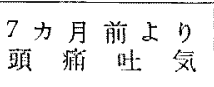 & 画柽度荻渎 & $"$ & 正中前後敩累露 & \\
\hline 5 & 19 & 8 & C O 中毒 & 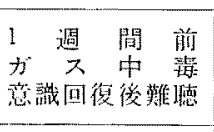 & 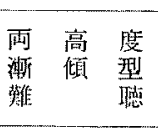 & $\mp-フ^{*} 2$ & 舆 & $\begin{array}{l}\text { TTS } \\
(-) y y \\
\text { リトx } \\
\text { ント ( }\end{array}$ \\
\hline 6 & 26 & $\partial$ & 精补分裂㾏 & 14 化并上り & 添卧正学 & 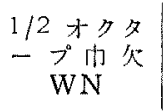 & 界 & 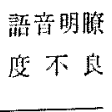 \\
\hline 7 & 10 & $\ominus$ & " & 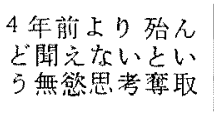 & 両怪度䧼聴 & " & $"$ & 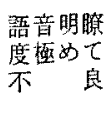 \\
\hline
\end{tabular}


後覚を示すようになり,本人も耳開塞感の減少を訴えた。

D) 小 括

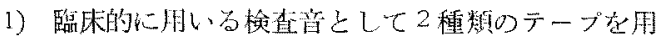
いた，第1 のテーブに PN, WN，および BN の䦤 数笔囲 $0 \sim 850 \mathrm{cps}, 850 \sim 2400 \mathrm{cps}, 2400 \mathrm{cps} \sim$ の b 0 . 5 種頪 $0.50 \mathrm{sec}$ 点を録密し SL 40 60db で聞か世，第 2 のテープには1/2才クターブ巾欠 WN $0.50 \mathrm{sec}$ 音党錄 音し, SL $20 \mathrm{db}$ 加 $10 \mathrm{db}$ づつ強くして聞か世る。検 查の方法杜基礎編で述へた方法をやや簡略化した，

2) 正常人にテープ1を聞がた所, 正中前後 $1 \mathrm{~m}$

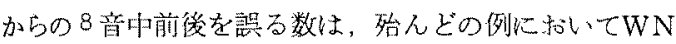
は1コ以内, BN 2400cps〜は2コ以内上なる。 その他

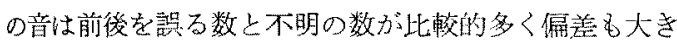
い, 左右側前後音比径しては WN, BN $2400 \mathrm{cps} \sim$ 点 共1コ以内となる、テープ2を闢かせた場合は各方向音

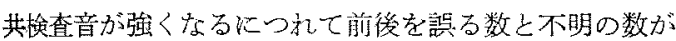
少くなり $40 \mathrm{db}$ 以上で殆どのとなる，そこで前後を埕 る数と不明の数が以上述へた数以下の場合を前後覚正常 と定わた。

3)上記のテープを用いて各種難㯖省の栺倦賞をしら ベた，正常人で前後の分りにくい, BN が各種㧥舁例で よく分ることは殆んどなかった。

i）神経性耳鳴 両耳㯖力偠注正常の7名についてし らベた所 2 名以異常が双られた。

ii) 神絽性難聴 各種 神程性 難㺊者 122 名について しらベた，高音聴力の低下と其に前後賞は悪化する。雨 側高音急壁型では幾分よい前後覚を有するが，雨側中侍

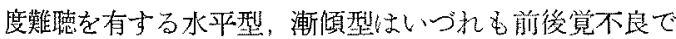
ある、检查音を強くしても前後党が良くならない例が多 い.

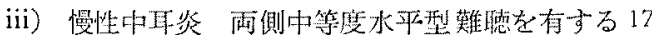
名では前後覚異常のものが多く，检査音を強くしても立亩 後觉が良くならない，例が多い慢性中耳炎術後舁者 13 名中, 鼓膜成班術後が前㣪覚良好でついで根治術がよく 鼓空成形術後例の前後覚は極めてわるい。

iv) 1 側整获推帵

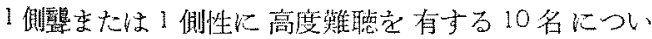
てしらべた所 80\%が3方向共前後觉不良を示した。1 側

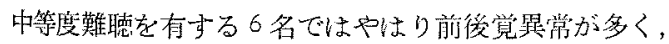
また良耳側 $45^{\circ}$ 万间音に対与る前後覚が思耳側のそれに 比して必ずしも良いと佷らなかつた。1 側轾度嚾聴を

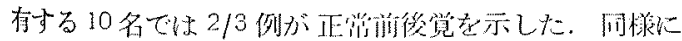

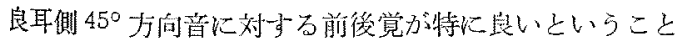

はなからた。1 側軽〜中等度難聴索有する10名につい

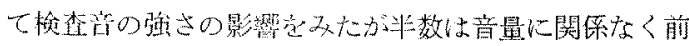
後筧異常を示した。

v) $x= \pm$ 儿上此

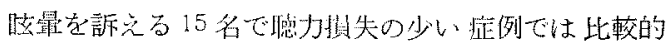

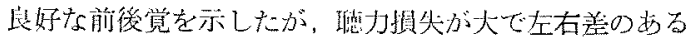

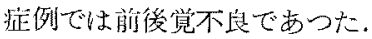

vi) 中枢疾蚛

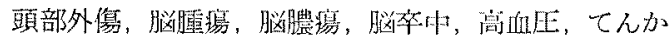
几，乙の他の中枢性疾㦙を有する39名についてしらへ

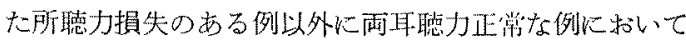

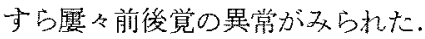

vii) 外耳疾舁

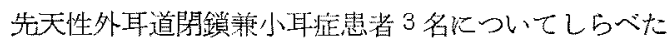
が，難聴の程度が大であるためるあつていつれも前後覚 は不良であつた。场揤を有する4名ではそのために 高音低下の方例に前後覚異常が多られた。

\section{IV 考按}

音の方向感覚は日常生活上単に物音の位䈯を知るばか りでなく，雑音の存在下で語音の明瞭度を良くする働き がある (König, Nordlund \& Fritzell 2)3), Belzile et $\left.\mathrm{al}^{4)}, \mathrm{Kock}^{5)}, \mathrm{Hirsch}^{6)}\right)$. さb飞近年中枢性疾患の䛦断 に方向覚検査がとりあげられるようになつてきた（Sanchez-Lengo 78), Forster, Matzker ${ }^{9}$ ), Langenbeck, Nordlund ${ }^{10)}$, 竹尾 ${ }^{11)}$ ).

著者は緒言に述べたごとき理由で特に前後の方向感の みについて砸究した，従来の音の力向覚に関する㖄究で 特にこの音の前後感に注目し考察を加えている例は極め て少い、以下本研究結果上諧芜の成績を比較する場合， 必ずしも前後方向の場合でないことがあるが，この点止 光定鳇ない。

研究は始めレシーバーより各種の音を聞かれ，その前 後を弁别さぜるといら力法を用いる予定で種々試及たが 前後感を有する音をレシーバーを通して作りだすこと は至難であることが分つた。繥局 2 コのマイクロホンを 䄪 $20 \mathrm{~cm}$ 唯し，それぞれの出力を音を聞く人の両耳にあ てたレシーバ一に尊き，両マイクロホンををれでれ対応 する耳の動きと同じように動かした時にのみ（簡単には マイクを聞き手の闻側頭部につける）音の前徭感が得ら れた（接続を逝に尗ると前後逆に聞える）、マイクロホン 安固定すると音は行に後頭部附近するいは頭蓋内で聞兑

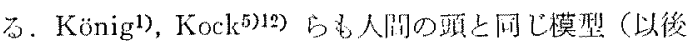

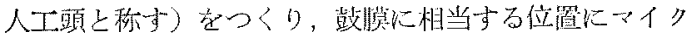




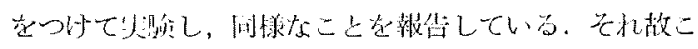

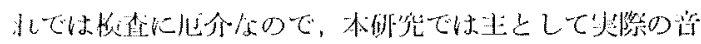

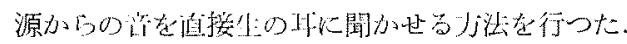

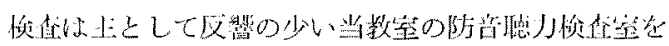

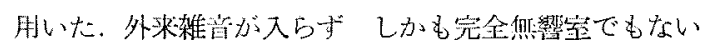

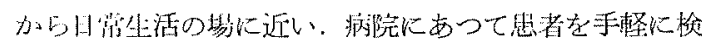
䄳しやすいといら利点もある、ただ響によつて定常波 が生じやすい点が問題であるが，本检查法のごとく梌查 音に複合音を用い，から両耳㯖で聞く場合々の影響忙ご く少いものと思わ机る。

前後覚は図1のごとく被㮥者の前後同一距㕍に市る音 源からの同じ强さの2 音を弁別する能力をしらべること によつて研究した。距滩は $1 \mathrm{~m}$ とし, 方角は主として

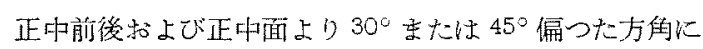
つて研究した。前後のスピーカーからは全く同一音が 出るように装珇に注意を払つたが，さらに検查音として 少しつう音色の異る音を選び，同一音はつつけて出さな いようにして装置による音色善を被检者にさとられぬよ らに心掛就た。

音の前後の答え力で少数の熟練した人を被検者とする ならば前か後のいつれか必ず答劣るよらに指示できる

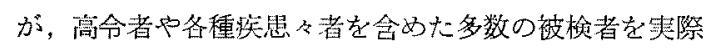
に検查する場合前倦不明という答やあるいは等して返答 しない場合が霓々双られた。これらも䛊りとは買つた意 味を有するものと考克られるが，さらに前の音を樭る場 合上後の音を誤る場合などと細かく分けて考党ると繁雑 なのでこれらを一括して取倣つた。

純音は定位し難く複合音は定位しや一い(Pierce， Firestone ${ }^{13)}$, Stevens ${ }^{15)}$, Whitworth \& Jeffress ${ }^{15)}$, 竹尾 ${ }^{16)}$ ). Stevens \& Newman ${ }^{17)}$ によ就純音でも

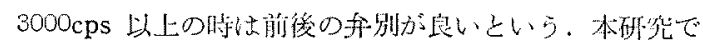

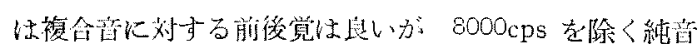

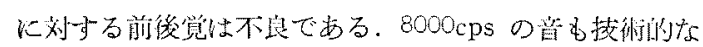
理由から雑音が湿入しやすいので必ずしも例外とはいい

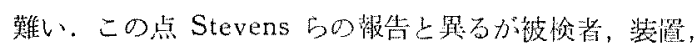
万法，場所の暹いによると考流られる。著者自身ビルの

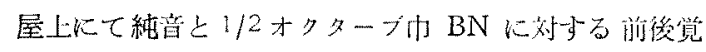

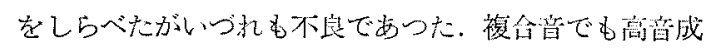
分のないものでは颕後の升別が蜼かしい。

人阔の頭の前方から来る音と後方から来る省の経路を

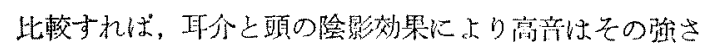

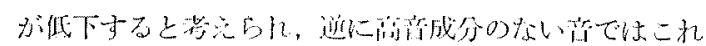
らの効果が現れない。このことより耳正頭の陰影初果

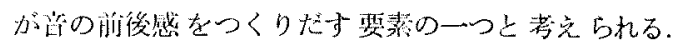

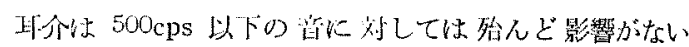
(Tröger, Sivian \& White, Steinberg \& Snow). \&

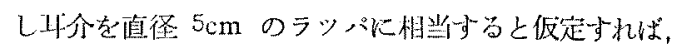
$3300 \mathrm{cps}$ 以上が集旨さ礼るといら(恩地 ${ }^{18}$ )。この耳介作 用がなくなるように形を装えたり蔽つたりすると方向覚 が瑟化する (Burnett, Münsterberg, Jongkees \&

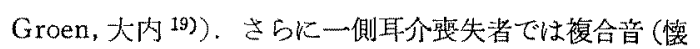
中時計音) の定位能が患側で非常にわるいという（藤田 20)）。著者もモルモットの耳分を切除した場合としない 場合の CM を各方獬音で測定し，耳分が高音に対し遮 音効果学有する $(2000 \mathrm{cps}$ 以上 $4000 \mathrm{cps}$ で顕著, 8000 cps では CM の測定困難）ことを認めた. Jongkees

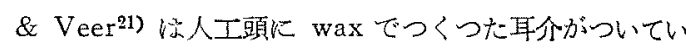
る場合とついていない場合の音の強さの polar diagram を画き耳介がないと角度によつて音の強さが一様化增減 ぜず音源側の耳軸以外飞第 2 の極大点を生じ，これが力 向聴を好げると述べている.

Nordlund \& Lidén 22), Sandel et al 23324), Sivian \& White ${ }^{25)}$, 村島 ${ }^{26)}$ らは人工頭や実際の人間を用いて 研究し，音源の方角が耳に入る音の強さに及ぼす影響に ついて報告している，いつれの測定結果に执いても0

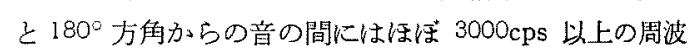
数で $5 \sim 10 \mathrm{db}$ の強度差が認められる，この僅かの違い を認識し前後の2音を弁別するものと考学られる。しか し全く未知の音加1正中前をたは後からきた場合，元 れが既に耳介によつて高音成分が低下しているのかいな いのか不明であるから前後の茾別山難かしくなる，既知 の音では記憶仩よつて判断していると考允られ，未知の

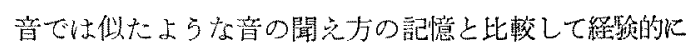
前後を判断していると考えられる。

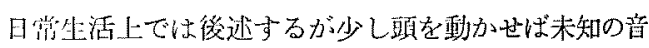

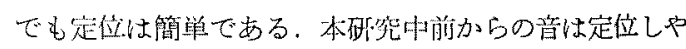
与く後からの音は定位し難い、例が時々 みられたことか

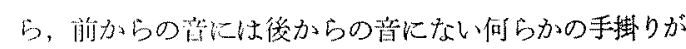
含まれている可能性もある. Nordlund27) の測定成績を

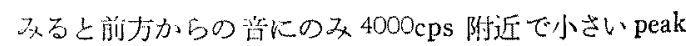
が㑇められる.この peak の存在によつて前方感が生 じるとも教学られたので，著者は自記オージオメータ 一を利朋して5人の正常人についてしらべたが，この

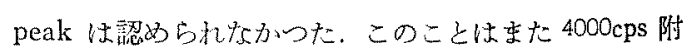

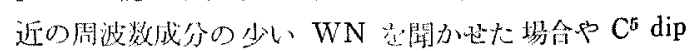

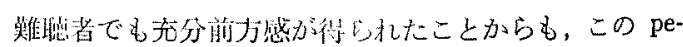


ak による前方斯成立機軖は疑わしい。

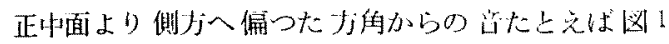

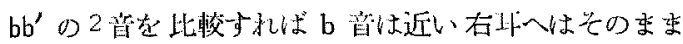

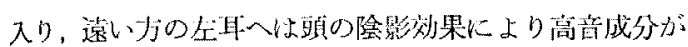

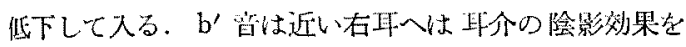

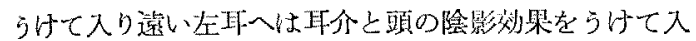

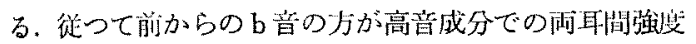
差加大きく後加50 b $b^{\prime}$ 音の时㤌小さい. Sivian \&

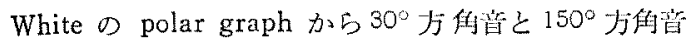
について近耳と遠耳の弦度差を周波数別に聲直してみる と図17のごとくなる。

图 $1730^{\circ}$ 方角音上 $150^{\circ}$ 少等音比刘する 画耳閶强度差の造い

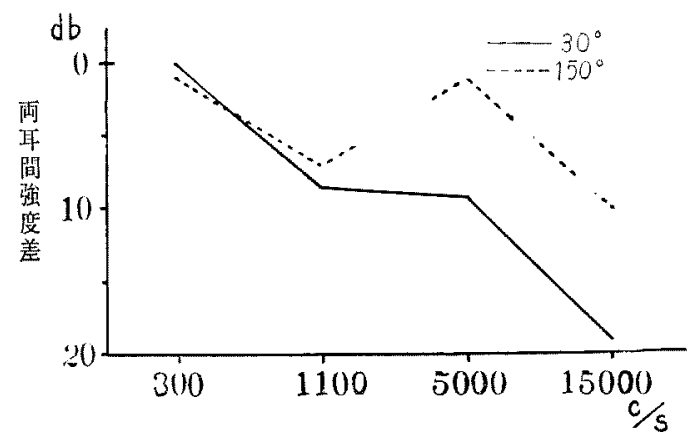

Nordlund, Sivian \& White, 村鼻加5の測定結果加

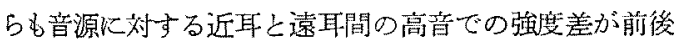
音間で最も大きく違つているのは $30^{\circ} \sim 45^{\circ}$ 附近である。 著者も自記オージィーターを利用して各牦度における 純音の䦪值を湘定し，あるいはモルモットを川盤台上で 廻し乍ら CM を測定することによつてこの罢装を確め た、このことはまた検查 15 の結果とも一致する.以上 述べたことき离音の左右の耳への聞え万の違いを涊識す ることにより前後を判断していると考党られる．徒つて 未知の音がーつ鳴つてす高音部の雨耳に入台音の間の強 度差の程度と偏倚度との組合わ甘で斿俊を判断しうるわ けである。これが正中前後音より，正中面より偏つた方 解からの音の力が前後が分りやすい理由と思小れる。

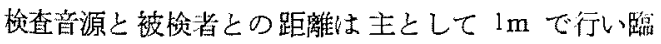
以的には簡便法として $45^{\circ}-135^{\circ}\left(315^{\circ}-225^{\circ}\right)$ 力问の

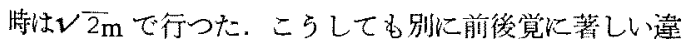

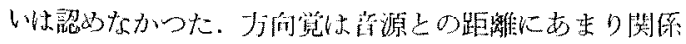
しないという频告もある(Firestone ${ }^{28)}$, Hornbostel).

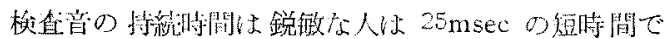

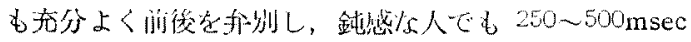

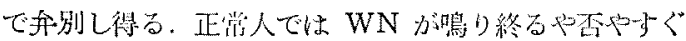

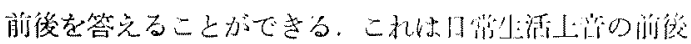
を焦意識の队に判断与る練習が自然にできているためと

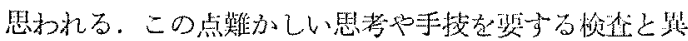
り，老人学童でも充分梌查できた.

検查音の立上り立下り時間は調べた籊明内では前後筧 に影劉を及はささなかつた。この点促来の立上り立下り

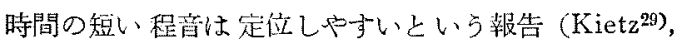
Godwin ${ }^{30)}$, Perekalin ${ }^{31)}$ ) とは異つている。純䄍では立 上り站下り㭙間を短くすると click が登生しや-すく，こ

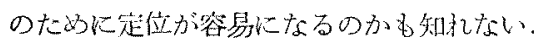

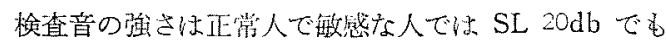
艮く前後音を弁別し，晋通の人でも $40 \mathrm{db}$ 以上で良い前 後覚が得られた，従来の研然でも SL $50 \mathrm{db}$ あるい㤝 分よく聞える強さで行つたなどといら報告が多い。この ように正常人では闌侹上30〜40db 以上あればよいが難 聴者を检查する埸合どの周波数の閔值上 $30 \sim 40 \mathrm{db}$ にす るか䦌題である。本研究ではテープ1のごとく $1000 \mathrm{cps}$ の閴值上 40〜60db（禣充琾象のある列では少く，高音 低下例では大きくした）とするかテープ2 のごとく10

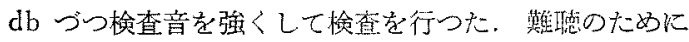
高音か聞党なくて艺のために前後覚の慧いものを仮性前 後覚不良，高音が聞えているに抱らず，前㣭觉の腎いむ のと真性前後筧不主已仮に名付けた力゙，慢性中国炎例で 賬々真性前後觉不良がみられたのは意外である。これは 恐らく中耳伝音機構の変化によつて入つてきた音の中の 前後感を止じる手掛りがここで歨加れるのでするら。

次滛被測の間題であるが，正常人について WN

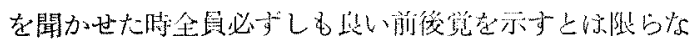

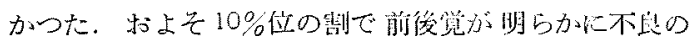

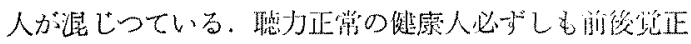
常者とはい方ない。

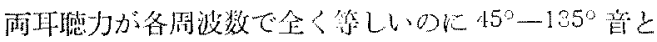

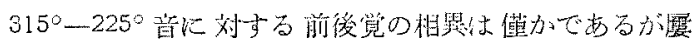

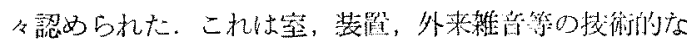

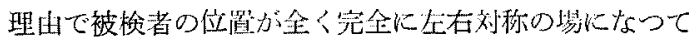

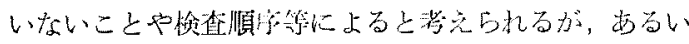

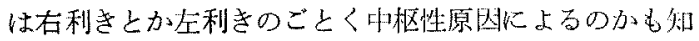
小大sw.

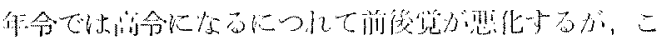
れは老人性蜼愊水よび老令に伴う中枢性然化のためとを 


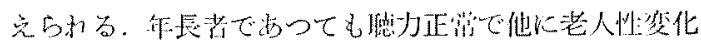

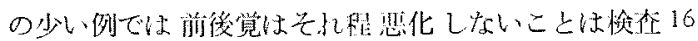

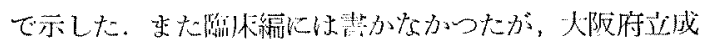

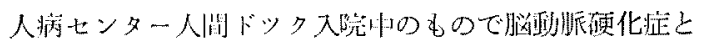

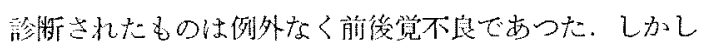

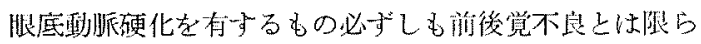
なかつた. Matzker \& Springborn ${ }^{22)}$ は4 才を過ぎ

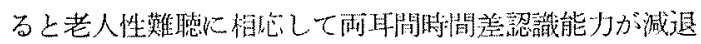
すると報告している。

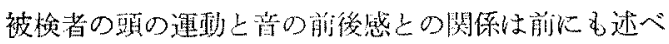
たが同様な報告は多い(Klensch $\left.{ }^{33}\right), K_{\text {önigi1), Kock }}{ }^{12)}$, De Boer). König \& Sussmann ${ }^{34)}$ (䫑の spontane movement t見出した。 Van Soest \& Groot, Wallach

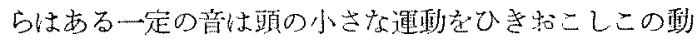
きにより定位がなされると述べている。

前庭賞と迷路刺韩の夙釈については Reinhold は刺

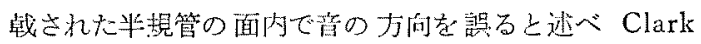
\& Graybiel, Jongkees \& Veer, 原口 ${ }^{35)}$ 万电枟後に

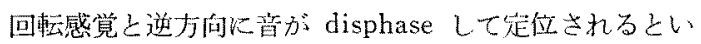
5. Tullio は loud sound で頭の動きをつくり, 前庭

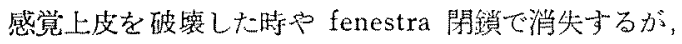
蝸牛を破蕒した時法そのま亦のこることを示した。

Meurman \& Meurman ${ }^{36)}$ は雨耳開空術後患者は正

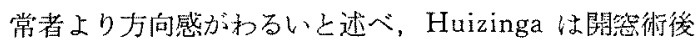

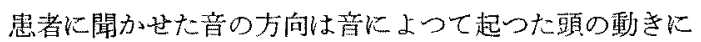
何ら影響を与えないことを諗めた。.Jongkeesは前庭の 温桨刺践中箩が偏位することを認め，また德力正常で前

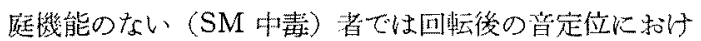
る虚倚はみられなかつたといら。

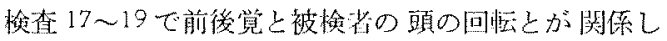
ていることを詛明したが，その際マイクロホンを雨側㽬 部につけその出力をそれぞれ反対側の耳に聞かせた理的

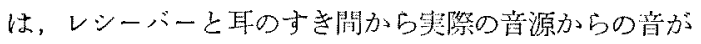
直接入つてきて串，それをレシーバ一乵が masking し

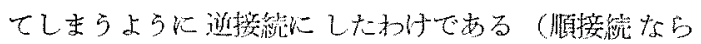

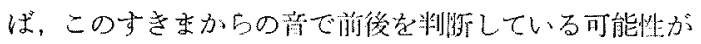

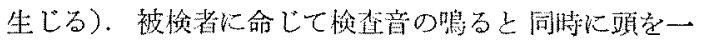
定角度だけ建す力法は被検者により上手下手がある。頭

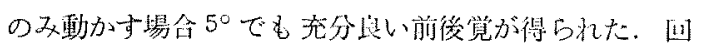

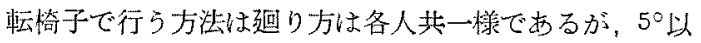

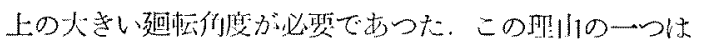

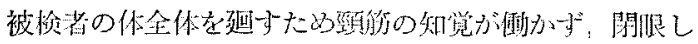

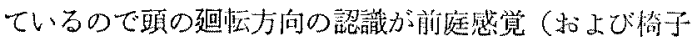

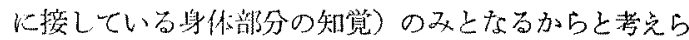

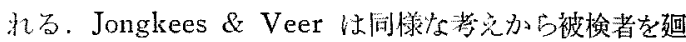

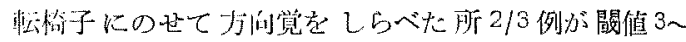
200 で定位阿能ですつた。一方 Diamant, Güttich ${ }^{37}$

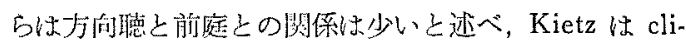

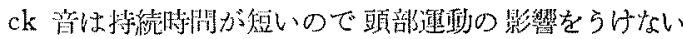
に抱らずよく定位されると述べ，Jongkees も開空術後 患者の今问覚のわるいのは術腔の存在によるのではない かと指摘している。

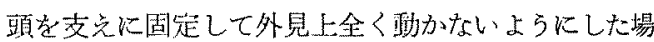
合と被㛟者自らが舫かさ欢よう注意した場合での前後

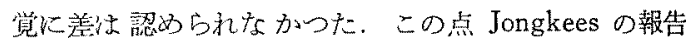
と一致する。

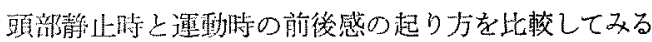
と前者の昜会では検查音の周波数籍用が层くてかい高音 を含えでいなければ良い前後覚が得られないのに反し，

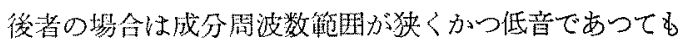
是い前後筧が得られた。このことから頭部運䡃時には别

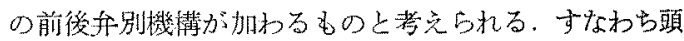
部静止時では頭や耳分の陰影効果による音全体としての 强度の変化，むるい恃両耳聞強度差を認識することによ り，運動洔にはそれ以外に頭の回転とそれに伴う両耳間 時間差，位相差，強度差の变化を認識すること化すり前 後を判断しているものと思方れる。このよらに方向知覚 の機構が二重になつていることは前媵覚のみならず方向 党一般についても同慊と思和れ，先に述ベた諸家の報告 がいるいると異つているのはこの二つの機横を分離して 考えていないためであるら。

実馀的に耳に防音プラグを装着したり，あるいは酸覚 疫等を起した時の力间感については報告が殆えどない。 近年工場での德覚瘦労の発坐や騒音対策として耳烃の装

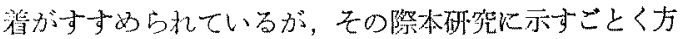

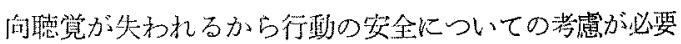

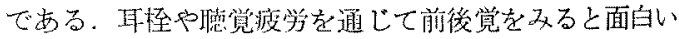
ことに者源に近い方の耳为主として㗢，裳い方の耳は

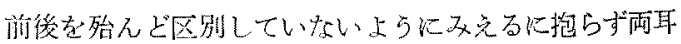

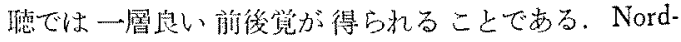
lund \& Fritzell² は騒音下での speech の片倒語音

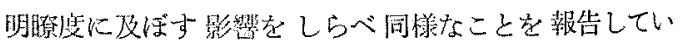

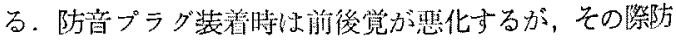

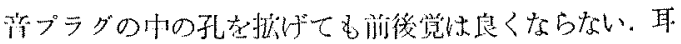

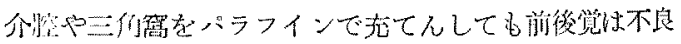

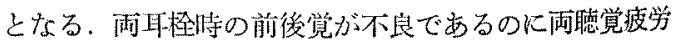


時の゙前後覚が良いのは，その低下度の違いにもよるが他 に耳栓では外耳道共鳴点が变り，耳介や頭の 陰影効果 をらけてスってきた音の中の前後感を生じる手掛りが変 化してしまうのに反し，聴覚疲労時は音はそのまま鼓膜 に達するので丁度 $4000 \mathrm{cps}$ 附近の成分の少い 音を聞い た場合と同様になるためと思われる。このような音は前 後茾別が容易である． $\mathrm{C}^{5} \mathrm{dip}$ 型難聴耳の前後覚も同様 飞悪くなからた， 1 側聴覚疲労時や 1 側耳柽時の前後覚 がよいのは，反対側の生の耳が優位に働くためと思われ る. これに反し1 側㹂では前後覚が悪いのは前後感上り 1 側惼倚感（音が真横で聞える）の方が強いためと思わ れる.

難㯖者の頭部静止時の前後覚は不良であることが多い の注常生活上方向覚不良を訴える人は案外少い，これ 蝢を動かすことに上り前後覚が良くなるので訴えが少 いす日と思われる。

高音急壁型神経性難聴例は会話は充分聞学るので本人 す周囲の人も聴力は良いと思っているが，前後覚が悪い のは日常生活上注意を要する。

老人性難聴例では難聴の程度に此例して前後覚が悪い が難㯖の程度からみて検查音が充分聞えている等である のに前後覚がわるい（真性前後覚不良）例が例い，これ は中枢性原因によるものと考学られる。 Matzker ${ }^{32)}$ は 老令者の両耳間時間差認識能力の 低下は脳幹の synaps の細胞の変性によるものと考光ている，Kōnig は年令 と共炕音の高さの弁別能が低下するといら。

触音間值正常の中枢疾患々者に括いて屡々高率江前後 覚異常者が認められた．このことから中枢疾患の診断に 前後覚検查が用いら礼る可能性がある，正中面より $30^{\circ}$ 〜 45 側方へ寄つた方角からの音に対する前後覚は既に 述へたことく両耳聴効果です゚つと良くなるから，むし中 枢障碍があつて両耳からの信号を比較し，あるいは隔合 できない時は両耳聴効果による前後音弁別能力の上昇は みられないと考党られる，正中前後音の升別は 1 側耳で むできる（表16参照）から兩耳聴テストとして用いら れない。

いま $0^{\circ}-180^{\circ}$ 音に対する前後弁別能を正中前後覚,

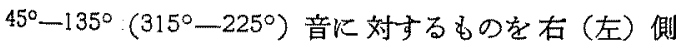
前後覚と略し，さらに前後弁別能のうち 1 耳だけに入つ てくる前後弁別の手挂りだけで判断する能力を一耳聴前 後覚，両耳からの音に含まれる手掛りを比較して判断す る能力を雨耳聴前後覚と仮に名つければ検査結果を次の ようにをとめられる。
1）正中前後覚もよいが左右側前後覚が一層良いもの ……1 耳聴前後覚も雨耳聴前後喾专よい（正常人).

2）正中前後覚が不良で左右側前後覚のよいもの…... 両耳聴前後覚良. しかし雨側の 1 耳耳聴前後覚が不良のも ので高令者に多い，被検者が全く未知の音を聞いた時も 和こりうる。

3）正中前後喾が良好で左右いつかか1側の前後覚不 良のもの……1 側の 1 耳聴前後覚が不良かあるいは网耳 聴前後覚不良の子の．中枢異常と考古られる．

4) 正中む左右側前後覚子不良……雨側の一耳聴前後 覚不良でから雨耳聴前後覚も不良のもので中枢異常と考 えられる。

以上は聴力正常で外耳, 中耳に異常の認められない症 例の場合であつて外耳，中耳，内耳等に病変がある場合 は当然前後覚に影響をらけるので中枢性原因による前後 覚不良とは断定できない。

頭部静止時の一耳耳聴前後覚が前と後の音を記憶して各 周波数での強さを経時的に比較することならば，その中 枢は比較的上位たとえば大脳皮質下にあり，両耳聴前後 覚は両耳に入る音の各周波数での強さを同時的に比較す るもので一耳聴前後覚よりも下位に，たとえば脳幹部な ぞに中枢があるのではなかろらか，さらに頭部運動時の 前後覚は両耳㯖前後喾と同し高さあるい山さらに下位と る考方られるが，頭の動きの認識が必要な点で平衡覚や 深部知覚の中枢と関連しているものと思われる。

とにかく本研究のごとき前後覚检查法を用いると聴力 正常で外耳拉よび中耳に異常の認められない中枢矣患々 者で高率に前後覚異常者が認められたことは注目に值す る. 後迷路性の障碍の診断法として前後喾検査法が用い られらることを示している，さらに病巣の部位患側につ いては症例数が少いので今後の研究の課題上したい

Sanchez-Lengo, Forster ${ }^{788)}$, Nordlund ${ }^{10)}$ らは側頭 葉隀湯患者では反対側の方向覚の異常を認めているので 前後覚も反対側の前後覚がわるくなるかる知的ない， Matzker は側頭葉以外飞脳幹，前頭，頭頂，後頭葉障 碍患者に方向覚の異常を認め，Nordlund は聴神経や橋 部の障碍は方向覚を悪くするが大脳障碍では正常方向覚

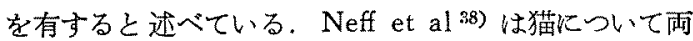
auditory cortex 破壊すると方向㯖はつよく障碍され るが auditory areas I， Iおよび Ep を雨側 ablation しても純音周波数の变化を升別する能力は失わないこと を示している。

両慢性中耳炎患者の前後賞は不良であるが特に中耳炎 
術後㭧者に著しい。これは難聴以外に外耳道膑つ変化や 中耳伝音機構の変化によると考点られる。

1 側難聴者の前後覚む難聴の程度に比例して悪くなる が必ずしも良耳側の前後覚が良いとは限らなかつた。こ

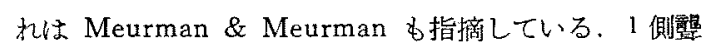
では㾫倚感がっよくて前後感は生じない，しかし10名中 1 名は正中前後音の 弁別のみ可能であつた. Jongkees \&Veer ${ }^{39)}$ は $1000 \mathrm{cps}$ 音を用いて方向党をしらべ，慢 性中耳炎患者のそれは正常に近いが感音系難德者では半

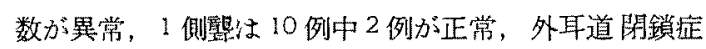
では異常, 鼓室成形術後例は $1 / 3 か ゙$ 異常, 耳硬化症およ びその術後例は全例が異常であつたと報告している。

日常よくみられる耳廐患者で前後覚が悪いのは與味深 い. 外耳道共鳴点が $4000 \mathrm{cps}$ 附近にある (Wiener \& Ross）といらから外耳道の形が変ると共鳴点が変化して 前㣪覚異常をきするのと思方れる。

\section{$\mathbf{v}$ 結 語}

1）被検者の正前唂拈上び正中面より一定角度だけ左 右へ偏した方角の前後 $1 \mathrm{~m}$ よりWN あるいは WN の成分周波数を一部变えた各種の音を聞かせてその前後 を当てさせるという方法に上り正常人総数 321 名につい て音の前後感覚をしらべ，さらに検查の簡便法を考えて 各種疾患々者総数 253 名について前後覚をしらへたた。

2）前後覚は検查音の性質に上つて影響される.成分 周波数籁囲が広くてから高音成分を多く含んでいる音程 前後の异別がしやすい，また高い周波数の $\mathrm{BN}$ は前に 定位されやすい。

㭘查音の強さと持続時間は前後を判断するのにある一 定の值 (SL $40 \mathrm{db}, 250 \mathrm{msec}$ ) 以上あ九ば充分である. 立上り立下り時間の影響は調べた範聿内では認められな からた。

3）音源位膡が正中面上にあるよりも正中面より $30^{\circ}$ 〜 45 偏した位置の方がよい前後覚を示すが，それ以上 離れると前後覚は再び悪化する。

4）被検者の頭の運動によつて前後覚はよくなる，そ の際頭部静止時では前啳の升別がしにくいBNでも， 前後の定位ができるよらになる。

5）実験的に聴覚疲労を起したりあるいは耳烃装着に 上り前後覚は悪化する。この効果は特に音源に近い方の 耳において著明である。

6）被検者の性別による差誻められなかつたが，年 令では老化と共に前後覚が覀化する.

7）難聴者の前後覚は難㯖の程度に比例して悪くな
る. 1 側嚾㯖者の前後覚も同様であるがその際必ずしも 患耳側の前後觉がわるいとは限らなからた。

8）中枢疾急及者では聴力正常のむのにおいてすら屡 々高率に前後覚異常者が認められた，このことより前後 敩検查が中枢疾患の診断に応用され得るものと考えられ る.

9） 以上音の前後感は頭部静止時は頭および耳介の隆 影効果による音全体としての各周波数での強さを䍿識す る能力 (一耳聴前後覚) と, その強さを両耳で比較する 能力（阔耳聴前後覚）飞基づいて生し，頭部運動時は強 度の他に耐耳に入る音の時間差，位相差も働いてこれと 頭の回転方向を組合わして前後感が生じるむのと思われ る.

\section{VI 參考文献}

1) Koenig, W.: Subjective Effects in Binaural Hearing, J.A.S.A. $22: 61,1950.2$ 2) Nordlund, B. and Fritzell, B.: The Influence of Azimuth on Speech Signals, Acta Otol., 56: 632, 1963. 3) Norlund, B. and Fritzell, B.: The Advantages of Binaural Hearing for the Understanding of Speech, Acta Otol. Suppl., 188:270, 1964. 4) Belzile, $M$. et al.: A Clinical Comparison of Monaural and Bilateral Hearing Aids worn by Patients with Conductive or Perceptiue Deafness, Laryngoscope, $69: 1317,1959$. 5) Kock, W.E.: Binaural Localization and Masking, J.A.S.A., 22 : 1950. 6) Hirsh, I.J.: The Relation Between Localization and $\mathrm{In}^{-}$ telligibility, J.A.S.A., 22: 196, $1950 . \quad$ 7) SanchezLongo, L.P. and Forster, F.M.: Clinical Signifcance of Impairment of Sound Localization, Neurology, 8: 119, 1958. 8) Sanchez-Longo, L.P., Forster, F.M., and Auth, T.L.: A Clinical Test for Sound Localization and Its Applications, Neurology, 7:655, 1957. 9) Matzker, J.: Two New Methods for the Assessment of Central Auditory Functions in Case of Brain Disease, Ann. of O.R.L., 68: 1185, 1959. 10) Nordlund, B.: Directional Audiometry, Acta Otol., 57: 1, 1964 . 11) 竹尾康男：音の㯖克 の方向感関する研究 その 2: 日耳鼻, 67；1272, 昭 39. 12) Kock, W.E.: J.A.S.A.; 20: 801, 1950.

13) Firestone, $C_{.}$: Binaural Localization of Pure Tones, J.A.S.A., 2: 271, 1930. 14) Stevens, S.S. and Davis, H.: Hearing 176, 1954. J. Wiley \& 
Sons. INC. 15) Whitworth, R.H. and Jeffress, L.A.: Time vs Intensity in the Localization of Tones, J.A.S.A., 33: 925, 1961。16) 竹尾康男: 音 の㯖えの方向感に関する研究その 1 ， 日耳鼻，67; 106, 昭 39. 17) Stevens, S.S. and Neruman, E.B.: The Localization of Actual Sources of Sound, Am. J. Psychol., 48: 297, 1936. 18) 恩地豊：伝音の理 論，耳啹科，24；578，1952.19）大内他：聴覚に 上る音方向知喾に関方万研究，日耳鼻，60；241，昭32.

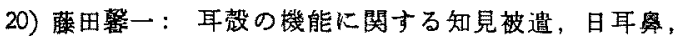
51 ; 288, 1947. 21) Jongkees, L.B.W. and Veer, R.A.. On Directional Sound Localization in Unilateral Deafness and its Explanation, Acta Otol., 49: 119, 1958. 22) Nordlund, B. and Lidén, G.: An Artificial Head, Acta Otol., $56: 493,1963$. 23) Sandel et al: Localization of Sound from Single and Paired Sources, J.A.S.A., $27: 842,1955 . \quad 24$ ) Sandel et al: Localization of High-Frequency Tones, J.A.S.A., 29: 988, 1957. 25) Sivian, J. and White, S.D.: On minimum audible sound field, J.A.S.A., 4: 288, 1933。26) 村島曷一：音源の方向 К上る聴力の変動について，日耳悬，62；704，1959.

27) Nordlund, B.: Physical Factors in Angular Localization, Acta Otol., $54: 75,1962$. 28) Firestone, $C$. The Phase Difference and Amplitude Ratio at the Ears due to a Source of Pure, Tone, J.A.S.A., $2: 260,1930$. 29) Kietz, H.: Neue Vorstellungen in Der Therrie Des Hörens, Z. Laryngol. Rhinol. and Otol., $36: 241,1957$. 30) Godwin, R.W.: Clinical Testing of Sound Localization,
Ann. of O.R.L., 70:976, 1961. 31) Perekalin, W. E.: Über die akustische Orientierung, Zeitschr. Hals-Nasen-Ohren-hlk, $25: 442,1930$. 32) Matzker, $J$, and Springborn, E.: Richtungshören und Lebensalter, Zeitschr. f. Laryngologie, 37: 739, 1958. 33) Klensch, H.: Beitrag zur Frage der Lokalisation des Schalles im Raum, Pflügers Arch. ges. Physiol., 250: 492, 1948. 34) König, G. and Sussman, W.: Zum Richtungshören in der MedianSagittal Ebene, Arch. Ohren-usw. Heilk., 167: 302, 1955. 35) 原口亭：聴覚における中枢性成分に関す る研究，日耳鬼，57；154，昭29. 36) Meurman, Y. and Meurman, $O .:$ Do the Semicircular Canals play a Part in Directional Hearing?, Acta Otol., $44: 542,1954$. 37) Güttich, A. Schallrichtungsbestimmung und Vestibularapparat, Arch. Ohrenusw. Heilk., 142: 139, 1936. 38) Neff, W.D.:

Behavioral Studies of Auditory Discrimination, Ann. of O.R.L., 66:506, $1957 . \quad 39)$ Jongkees, L. B.W., and Vesr, R.A.: Directional Hearing Capacity in Hearing Disorders, Acta Otol., 54: 75, 1962.

稿を釉るに当り，終始御㥶第なる御指䓕之御校閲 を賜つた恩師長谷川高敏教授に深甚なる感謝の意を 表します。

本論文の要旨は第 $117,118,119,123,124$, 125 回日本耳奥鸣啹科学会大阪地方会において演述 した.

（原稿到着=炤和 40.7 .19 日） 